\title{
Agriculure
}

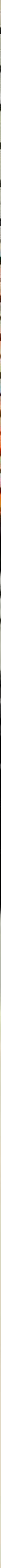

\section{STRAWBERRY CULTURE}

in Eastern Canada

630.4

C212

P 1585

1976

(1985 print) 
PUBLICATION 1585E, available from

Communications Branch, Agriculture Canada, Ottawa K1A 0C7

OMinister of Supply and Services Canada 1976

Cat. No. A53-1585/1976E ISBN: 0-662-00220-2

Printed 1976 Reprinted 1985 5M-1:85

Également disponible en français sous le titre

Culture du fraisier dans l'est du Canada. 


\section{GENERAL INTRODUCTION 5}

SELECTING THE SITE 5

SOIL 5

WATER DRAINAGE 5

AIR DRAINAGE 6

WATER FOR IRRIGATION 6

EXPOSURE 6

PREVIOUS CROPS 6

PREPARING THE SOIL 6

FERTILIZING 7

FUMIGATING THE SOIL 7

PLANTING 8

TIME OF PLANTING 8

PLANTING STOCK 8

PLANTING SYSTEMS 9

NUMBER OF PLANTS PER HECTARE 9

HANDLING THE PLANTS 10

DEPTH OF PLANTING 10

SETTING THE PLANTS 10

CARE OF THE PLANTING 12

CULTIVATING 12

CONTROLLING WEEDS 12

REMOVING BLOSSOMS 12

RUNNER SPACING AND THINNING 12

\section{IRRIGATING 14}

MULCHING 16

FROST INJURY 18

POLLINATION AND MISSHAPEN BERRIES 19

HARVESTING AND HANDLING 20

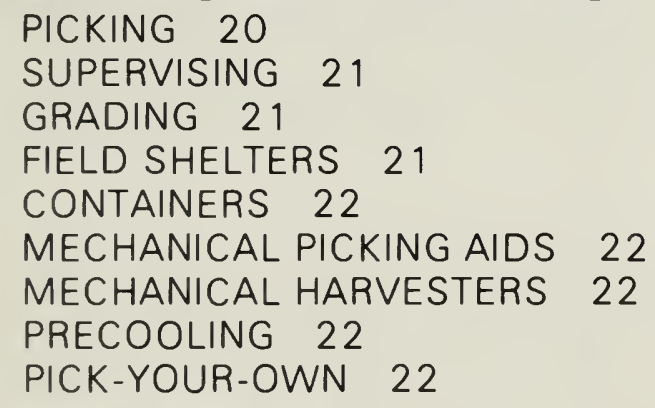

RENOVATING 24

EVERBEARING STRAWBERRIES 24 
STRAWBERRY PESTS 25

PESTS THAT ATTACK ROOTS 26

PESTS THAT ATTACK LEAVES, BLOSSOMS, OR FRUIT 26

STRAWBERRY DISEASES 30

FRUIT ROTS 30

ROOT DISEASES 32

FOLIAGE DISEASES 34

VIRUS DISEASES 38

LIST OF CREDITS FOR ILLUSTRATIONS 40

ACKNOWLEDGMENTS 40 


\title{
STRAWBERRY CULTURE in Eastern Canada
}

\author{
D.L. Craig \\ Research Station, Kentville, Nova Scotia
}

The strawberry is Canada's most important berry crop. It is grown commercially and in home gardens throughout all the provinces in Eastern Canada. Ontario is the leading fruit producer, followed by Quebec, and then the Atlantic Provinces. These areas produce $70 \%$ of the strawberries grown in Canada.

The strawberry is popular with home gardeners because it is easy to grow and the requirements of a family can be grown on a small plot of land. Commercial farmers find that the strawberry fits in well with a mixed farming operation or as a one-crop enterprise. Strawberries offer a quicker return on capital outlay than any other fruit crop. No other fruit yields more per unit of cultivated land in so short a time.

Climatic conditions in Eastern Canada are favorable for strawberry production. The strawberry plant is very responsive to length of day and temperature. The long warm days of late spring and early summer are necessary for runner plant development, whereas the cooler temperatures and the short days of late summer are required for floral development. The flowers that produce the crop are all formed during the fall before the cropping season. None are formed in the spring. Therefore, successful cropping is dependent upon the performance of many timely cultural practices.

This publication contains information on how to grow strawberries on a commercial scale. However, the practices and principles described also apply to growing strawberries in the garden for home use or for roadside stands. This publication does not contain specific recommendations on pesticide control, fertility, or varieties. Consult your local agricultural authorities for the most recent recommendations.

\section{SELECTING THE SITE}

In selecting the actual site for a planting. several factors are important, including soil, surface water drainage, air drainage, water for irrigation, exposure, and previous crops.

\section{SOIL}

Good soil is important. Deep, sandy loam soils, which are well supplied with humus, are ideal because they are well drained and hold moisture well. Soil moisture is essential for high yields.

Avoid coarse and gravelly soils. They need more plant food and water to support a strawberry crop. Avoid soils that have a high content of clay. because they are usually poorly drained and very difficult to manage. Good soil drainage is necessary because strawberry roots will not grow well in wet soil.

\section{WATER DRAINAGE}

The field should have enough slope and be free of depressions for surface water to drain away quickly. Strawberries are harmed by standing 
water even in a day or two, especially when the plants are growing actively.

If the only land available for growing strawberries is low and poorly drained, plant them on slightly raised ridges. Examine soils that do not drain readily for hard pans. Drainage under these conditions can be improved by breaking the cementlike deposits with tractor-drawn tool bars and by the use of tile drains. Avoid low-lying areas near rivers or brooks that are known to flood. On moderate slopes, plant strawberries on the contour to prevent soil erosion. Do not use steep slopes.

\section{AIR DRAINAGE}

Select a site with good air drainage to avoid injury to blossoms by spring frost. Cold air from well-drained areas moves to the low-lying areas, which should not be used for strawberry plantings.

\section{WATER FOR IRRIGATION}

Irrigation produces higher yields. When selecting a planting site, choose one near a good supply of irrigation water. You may need a permit to take water for irrigation and approval for construction of ponds and dams. Check with your local authorities for information.

\section{EXPOSURE}

Plants on sunny, southern slopes grow earlier and fruit ripens faster than the plants on the cooler, northern slopes. A southern slope is advantageous for producing berries for the early market. However, because growth is earlier. the danger of injury by spring frost is greater on a southern slope.

On windy sites, a windbreak can promote earlier ripening and prevent strong winds from drying out plants and from blowing mulch out of place. Do not locate windbreaks in areas where they prevent air drainage.

\section{PREVIOUS CROPS}

Do not grow strawberries in soils where raspberries, potatoes, tomatoes, eggplants, or peppers have grown within the past 4 years. These crops are susceptible to verticillium wilt and, although they may not appear to be diseased, they infect the soil with the fungus. Most strawberry varieties are susceptible to the disease and, when they become infected, wilt and die. Verticillium wilt may also be a problem when strawberries are planted following the removal of a peach or cherry orchard.

Do not plant strawberries in the same soil each year. If you do not use crop rotation, the diseases that can cause strawberry root rot increase in the soil. For best results, follow a crop rotation of several years. Use crops such as grains and clovers that are not susceptible to root rots.

\section{PREPARING THE SOIL}

Organic matter that is plowed into the soil is really its "life blood". It provides plant food, improves the physical properties of the soil, promotes the growth of helpful soil organisms, and increases the water-holding capacity. To prepare the soil before planting strawberries, plant a row crop followed by a green-manure crop, such as rye, buckwheat, oats, or millet. A greenmanure crop before strawberries should be well fertilized to obtain maximum growth, which will in turn increase the soil humus content. 
Weed-free animal manure at the rate of 45 tonnes/ha (20 tons/ac) is another way to improve the organic content of soil. Lesser amounts of 11 tonnes/ha (5 tons/ac) of poultry manure can also be used. Apply poultry manure in the fall. Fresh poultry manure in contact with strawberry roots causes severe injury.

\section{FERTILIZING}

Soil must be tested to establish acidity and fertility levels. The kind and amount of fertilizer used will depend on the soil, the soil test, and the previous crops grown on the field. The application of the correct amounts of fertilizer will produce better strawberry yields than unfertilized or improperly fertilized plantings.

Good strawberry crops have been grown on soils ranging in pH from 5 to 7. Soils having a $\mathrm{pH}$ level lower than 5 may be low in available calcium and magnesium. The application of dolomitic limestone increases calcium, magnesium, and soil pH. Dolomitic limestone should be spread 6 months to 1 year before planting and should not be applied at the same time as commercial fertilizer. Combining these two may cause a tie-up of plant food in the soil. When phosphorus and potassium are needed, apply them in the fall before planting. If strawberries are to be planted following a fertilized green-manure or row crop, additional preplant fertilizer applications are usually not necessary. In the planting year, a nitrogen application as a sidedressing should be made 4 to 6 weeks after planting. depending on plant growth and runnering.

Nitrogen may also be applied in mid-August to increase the number of flower buds that form during late summer and fall. Strawberries growing in well-fertilized soil should not require more nitrogen at this time. Large quantities of nitrogen may reduce the number of flowers or cause too many to form. In the absence of irrigation, excess flower development increases the number of small berries. Spring applications of nitrogen in the fruiting year are not recommended for strawberries that have made normal growth the previous season. Plantings deficient in nitrogen may respond to an early ( 7 to 14 days after straw removal) spring application of nitrogen. Such an application should increase the size and number of fruit, with little effect on fruit rot and firmness.

Strawberry plantings often produce fruit more than once. Some renovation may be necessary after each fruiting; apply either nitrogen or a complete fertilizer as part of the renovation procedure to keep plants in an active state of growth. Consult your local agricultural authorities for the most recent recommendations.

\section{FUMIGATING THE SOIL}

Soil fumigation effectively controls nematodes. Fumigation is beneficial when strawberries are to be planted in fields known to have high numbers of nematodes. Nematodes injure strawberry roots by feeding on them. They also make small openings on the surface of the roots that allow fungus diseases, which cause root rot to enter. Controlling nematodes reduces the losses from root rot.

Fumigate the soil in the fall of the year before planting, when soil temperatures are $10^{\circ} \mathrm{C}\left(50^{\circ} \mathrm{F}\right)$ or higher. This allows the fumigant to act in the fall, then the soil is left over the winter, and strawberries can be planted safely in the early spring. Spring fumigation delays planting for several weeks and therefore is not recommended. 


\section{PLANTING}

\section{TIME OF PLANTING}

Plant as early in the spring as it is possible to prepare the land, usually late April or early May. Early planting allows the plant to produce runner plants in July. This is an advantage because the early formed runner plants produce much more fruit than those that are formed during late summer and fall. The crown and root system of late-formed runners are too small for good cropping.

Fall planting is not suggested because the yield the following summer is too low to justify the extra expenses, such as weed control and mulching for winter protection. It is also difficult to buy a supply of plants early in the fall.

\section{PLANTING STOCK}

Use dormant plants which have been dug early in the spring before growth has started or fall-dug plants that have been held in cold storage at $-2.2^{\circ}$ to $-1.1^{\circ} \mathrm{C}\left(28^{\circ}\right.$ to $\left.30^{\circ} \mathrm{F}\right)$ during the winter. Do not plant growing plants because they have used up their reserve food and do not grow well.

Plant Certified stock. It is wasting money to use noncertified plants. These plants may be partly or completely virus infected. Virus diseases, which reduce vigor and yields of strawberries, are spread by aphids, common pests in Eastern Canada. Aphid control is difficult, requiring isolation of Certified plants from fruiting fields and applications of insecticides.

Many nurserymen in Eastern Canada specialize in growing Certified strawberry plants. They cooperate with the Provincial and Federal Departments of Agriculture in an effort to produce healthy stock (Fig. 1). This stock is not completely free of virus or other diseases, but it is the best stock available (Fig. 2).

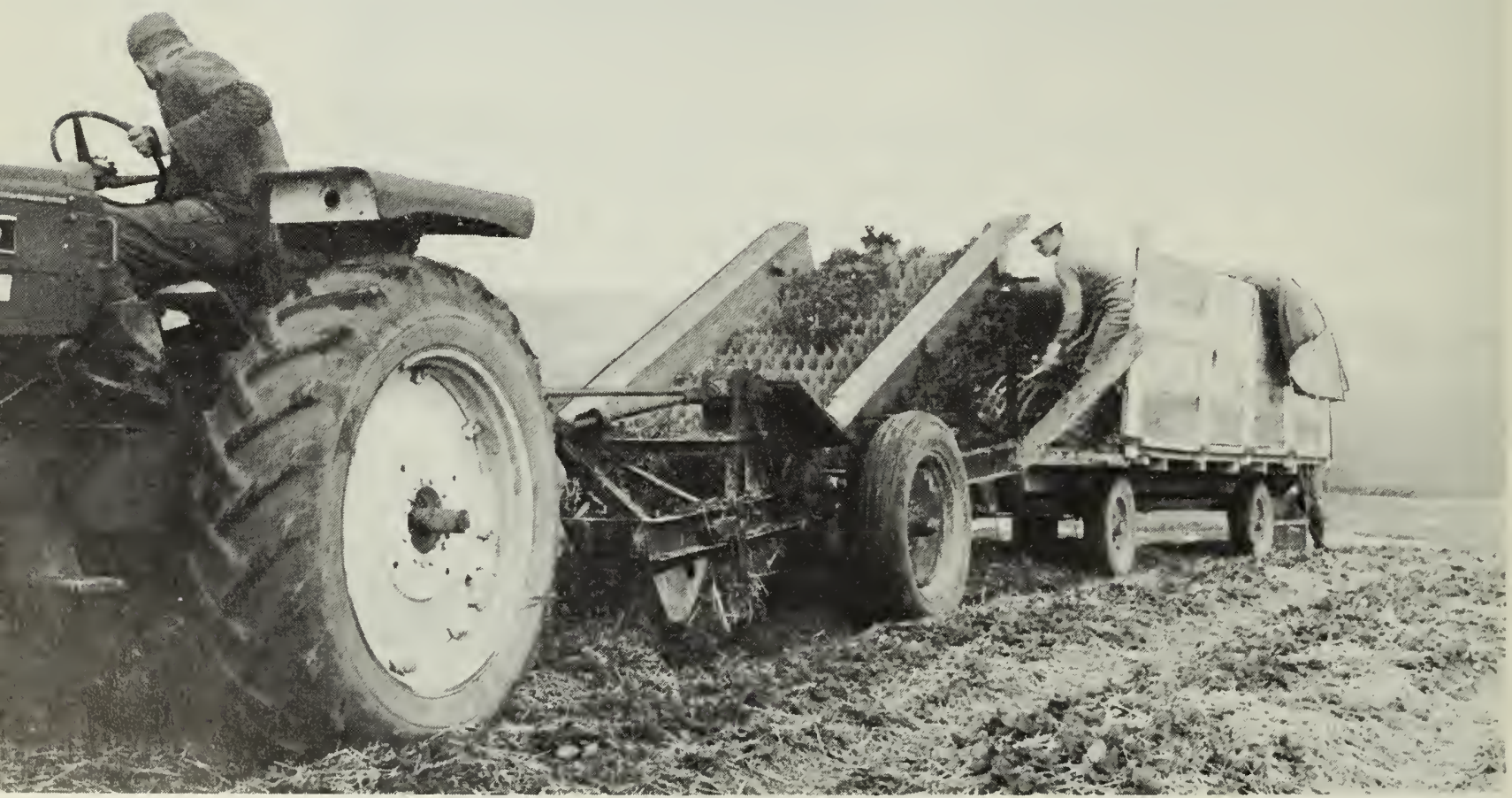




\section{PLANTING SYSTEMS}

There are many planting systems. The one best suited to Eastern Canada is the matted row. Set plants 61 to $76 \mathrm{~cm}$ (24 to $30 \mathrm{in}$.) apart in the row. Runners from these plants are allowed to root until the desired number of plants has been obtained. In areas where water remains in the row during winter mild spells or at other times, it is best to plant on a raised bed 10 to 15 $\mathrm{cm}$ (4 to 6 in.) high.

A narrow row width of 46 to $61 \mathrm{~cm}$ (18 to $24 \mathrm{in}$.) is also recommended. This width of row is easier to weed and harvest than wider rows; it produces larger fruit and is usually less infected with foliar and fruit diseases. The row width can be varied to allow for the wheel spacing on the equipment you use for maintaining the planting.

\section{NUMBER OF PLANTS PER HECTARE}

The number of plants needed to plant per hectare can be determined as follows:

Multiply the distance between plants in a row by the distance between rows, divide this number into the number of square meters in a hectare (square feet per acre), and the result is the number of plants required for the spacing.

NUMBER OF STRAWBERRY PLANTS NEEDED FOR VARIOUS SPACINGS

\begin{tabular}{cccccc}
\hline \multicolumn{2}{c}{$\begin{array}{c}\text { Space } \\
\text { between rows }\end{array}$} & \multicolumn{2}{c}{$\begin{array}{c}\text { Space } \\
\text { between plants }\end{array}$} & \multicolumn{2}{c}{$\begin{array}{c}\text { Number of plants } \\
\text { required per }\end{array}$} \\
& $f t$ & $m$ & $f t$ & hectare & acre \\
\hline 1.5 & 5 & 0.60 & 2 & 11111 & 4356 \\
1.5 & 5 & 0.75 & $21 / 2$ & 8888 & 3485 \\
1.2 & 4 & 0.60 & 2 & 13888 & 5445 \\
0.9 & 4 & 0.75 & $21 / 2$ & 11111 & 4356 \\
0.9 & 3 & 0.60 & 2 & 18519 & 7260 \\
\hline
\end{tabular}

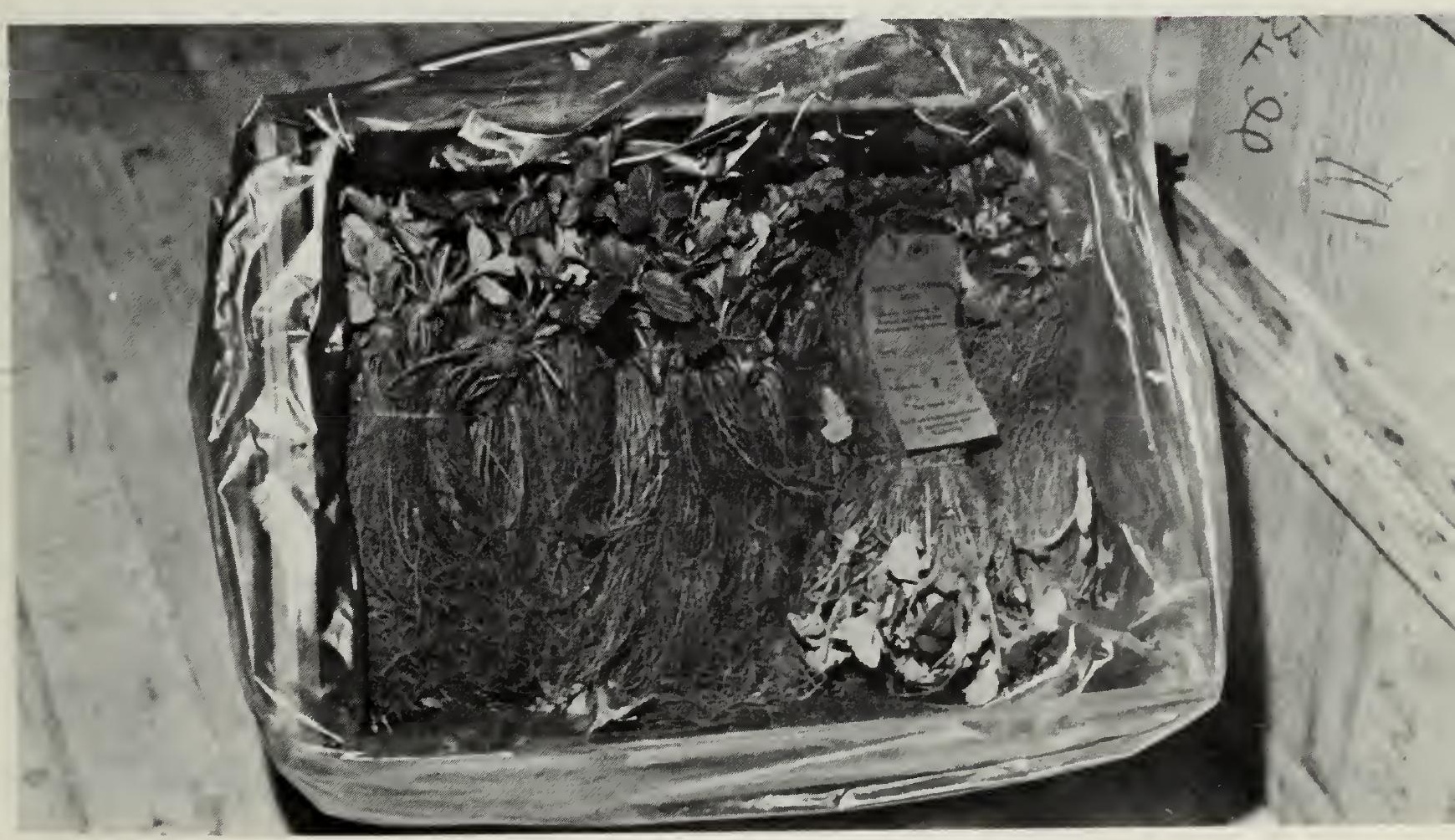




\section{HANDLING OF PLANTS}

Obtain plants as close to planting time as possible. If you cannot plant them as soon as you receive them, place the plants in a cool place that is shaded from the sun. If there is likely to be a long delay, store them at a temperature above freezing but below $4.4^{\circ} \mathrm{C}\left(40^{\circ} \mathrm{F}\right)$. If you do not have a cold storage room, dig a narrow trench in soil that is well drained, spread the plants out in the trench, and firm the soil around the roots. Protect the tops of the plants from direct sunlight and wind.

Do not allow plants to dry out during planting. Handle plants very carefully when it is sunny and windy. The very fine root system will dry out within a few minutes if it is not covered. If the roots are dry, place them in water long enough to wet them and then allow the excess water to drain off. Do not leave the plants submerged in water for more than a few minutes.

\section{DEPTH OF PLANTING}

Set plants so that the midpoint of the crown is at the level of the soil surface (Fig. 3). If set too deep, runnering is delayed and the growing point of the crown may rot. If set too shallow, the crown and tops of roots will dry out.

\section{SETTING THE PLANTS}

MECHANICAL PLANTING - Commercial growers use a mechanical transplanter (Fig. 4), which when operated by an experienced crew, can set more than 20,000 plants per day. Apart from speedy planting, the transplanter supplies each plant with water or a solution of water and plant starter. When using a transplanter, remove all excess foliage from the plants and use plants of the same size. The main difficulties with machine plantings are getting the roots in straight and deep and firming the soil around them. Prepare the land carefully to avoid these problems. A man following the transplanter can set any plants not properly planted by the machine.

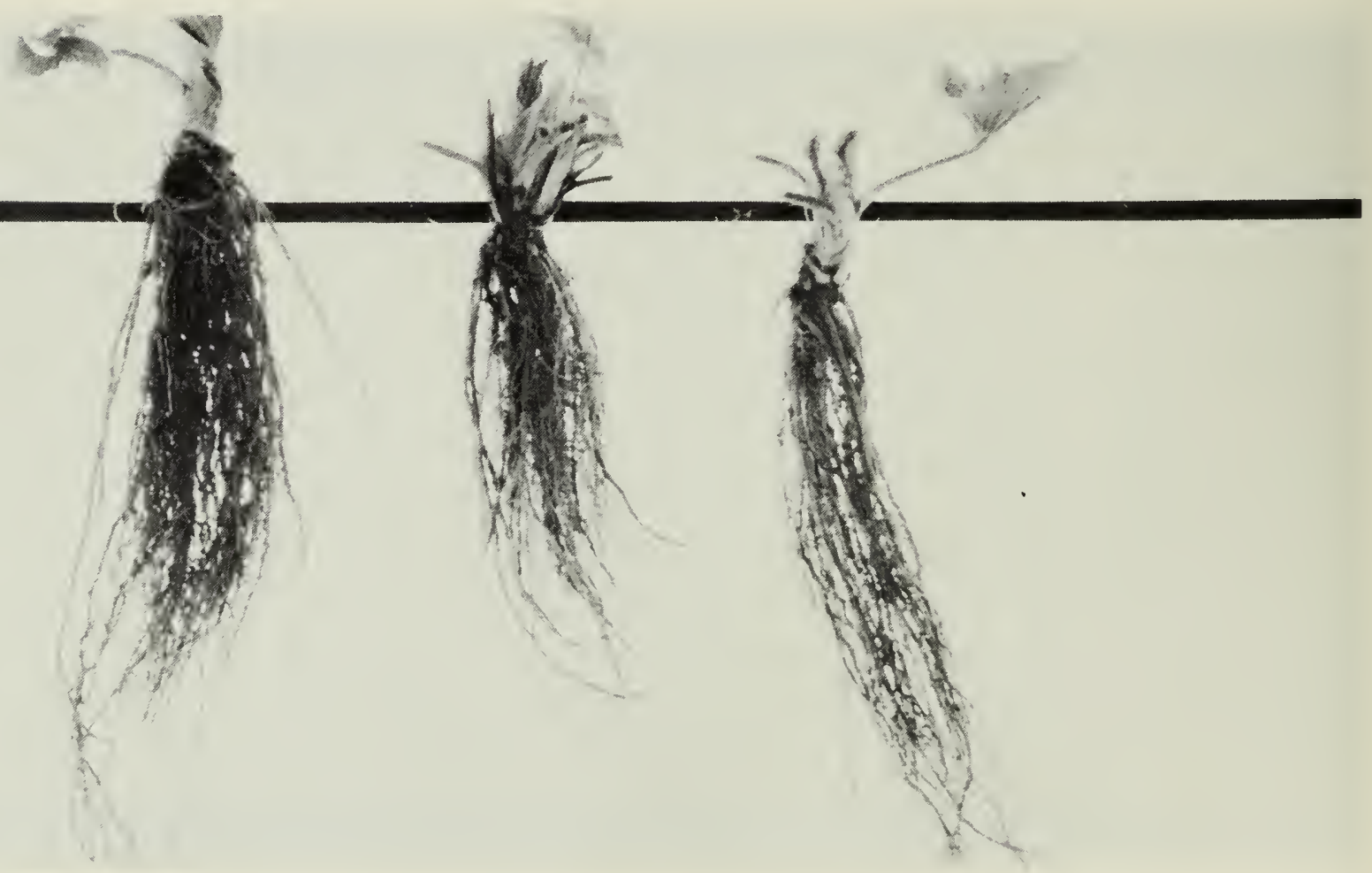




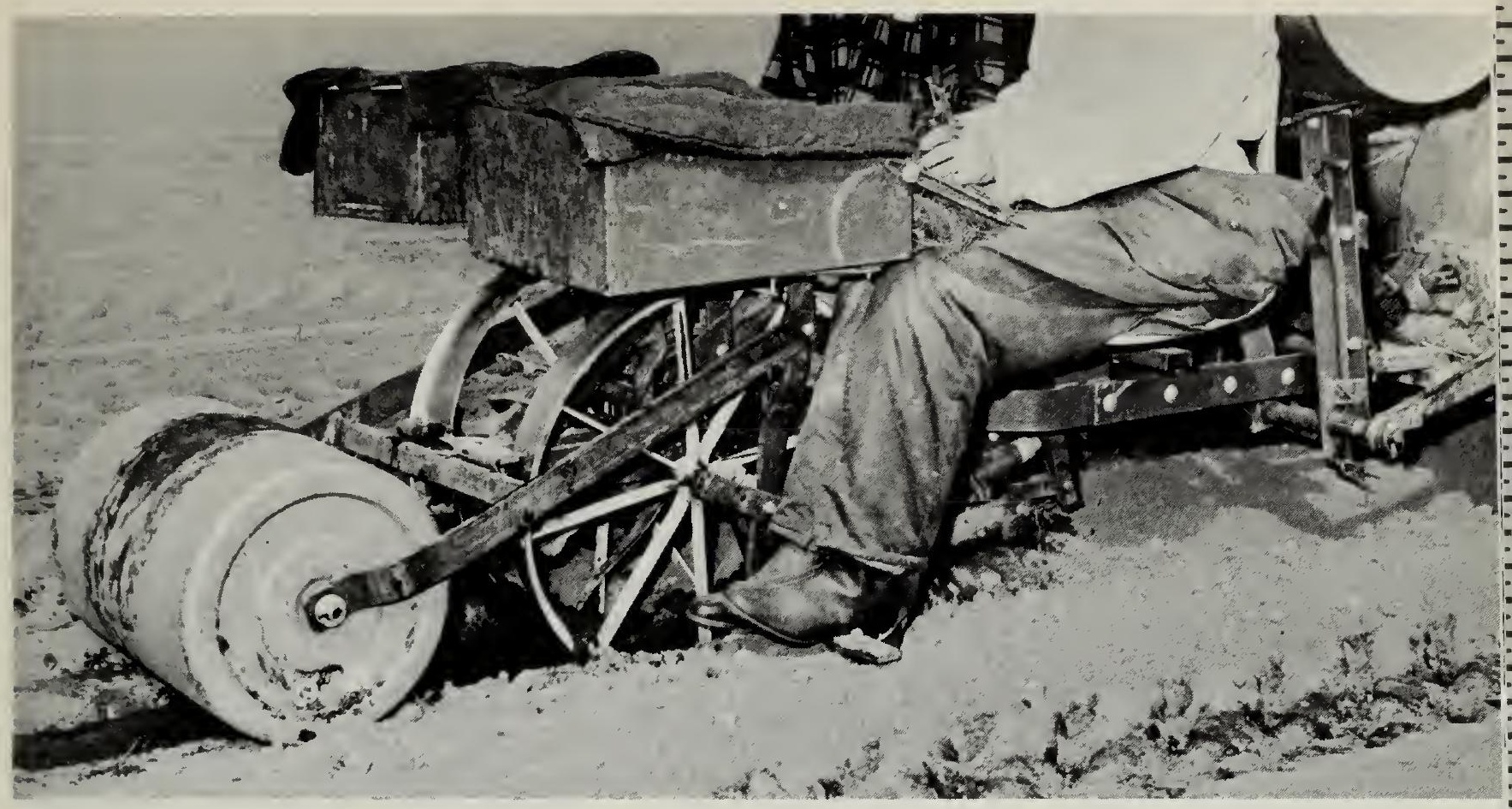

Fig. 4 A mechanical transplanter reduces planting time and provides water for the newly set plants.

HAND PLANTING - Hand planting requires two people working together. One person uses a spade or shovel, turning it backwards and inserting it into the soil. By moving the handle forward and backward, he forms a wedge-shaped hole in front of the spade. The other person places the plant (Fig. 5), with its roots straight down and somewhat spread, into the hole. The first person then withdraws the spade and firms the soil around the plant, being careful not to injure the crown.

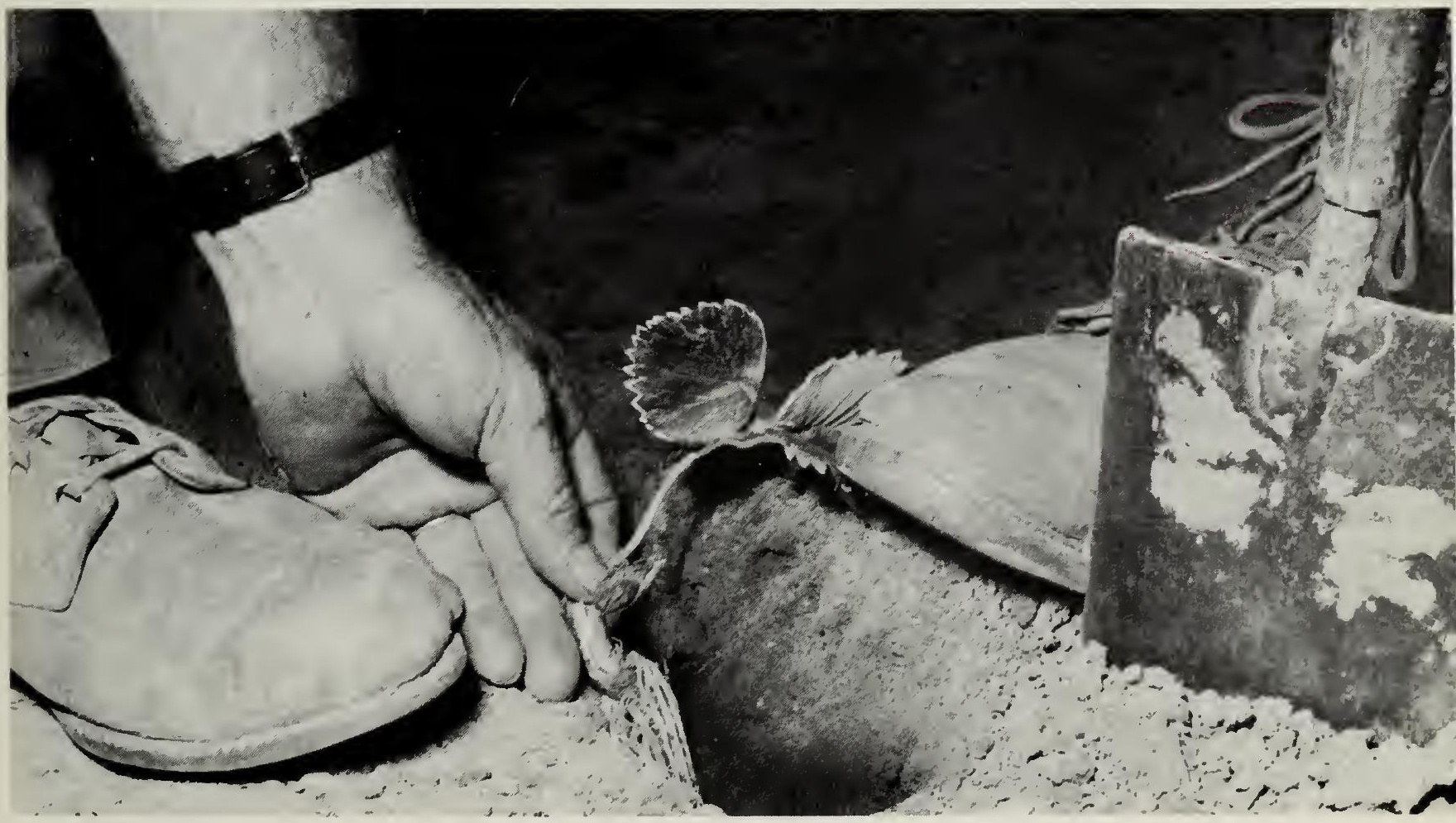

Fig. 5 Small plantıngs are set by hand. One man makes the openıng. and the other sets the plants. 
The yield and quality of the crop depends largely on growth and runner development made during the first summer after planting. It is, therefore, important to pay special attention to cultural operations such as cultivation, weed control, and irrigation, which encourage development of strong plants and early runners.

\section{CULTIVATING}

The increased use of herbicides has greatly reduced the need of frequent cultivating and hand-hoeing for weed control. To prevent crusting. cultivate shallowly, thereby improving the rooting of early formed runners, training the runner plants along the row, and improving the effectiveness of some herbicides. Avoid deep cultivation. The strawberry root system is shallow and easily injured by cultivation. Deep cultivation decreases the moisture supply of the soil.

Cultivate the rows in the same direction to prevent disturbing rooted runner plants (Figs. 6 and 7). Permit the rows to become wider with each cultivation. When the desired row width is obtained, remove the excess runners with the use of a rolling colter, a rototiller, or some other means. Some hand-hoeing may be needed to remove weeds that have not been controlled by the herbicide and to move runners that inhibit good spacing. Do not pull soil away from the plant with the hoe. Hoe toward the plant but avoid covering the crown with soil.

\section{CONTROLLING WEEDS}

Perennial weeds, particularly quack grass, are a major problem for strawberry growers. They must be removed before planting strawberries. Start your control measures the year before planting.

Herbicides and tillage effectively control weeds in strawberry plantings. When properly used, they greatly reduce the number of cultivations and the amount of hand-hoeing. The selection of which chemical to use will depend on the kind of weeds present and the time of year the spraying is done. The amount of the chemical to use depends on soil type. Chemical weed control is a rapidly changing field with new herbicides being made available each year. Consult your local agricultural authorities for the latest information.

\section{REMOVING BLOSSOMS}

Remove the flower stalks from newly set plants to produce earlier and increased runnering. Remove the blossoms when the entire stalk can be picked off. Some varieties produce only one flower stalk and others produce several stalks on each plant. It may be necessary to check the planting two or three times to remove all blossoms.

\section{RUNNER SPACING AND THINNING}

A serious fault of the wide matted row system is that too many plants develop. If this happens, yield and berry size are reduced because of competition for water, food, and light. Pollination may be poor and more diseases present, especially botrytis fruit rot. Generally, four to six plants per $0.09 \mathrm{~m}^{2}$ (1 sq ft) are best; this means 10 to $15 \mathrm{~cm}$ (4 to $6 \mathrm{in}$.) between plants. Draw runners produced after the desired spacing has been reached into the alleys between rows and cut them off with a device such as a rolling colter. Some growers use a dump-type hay rake to pull the runners into the alleys. 


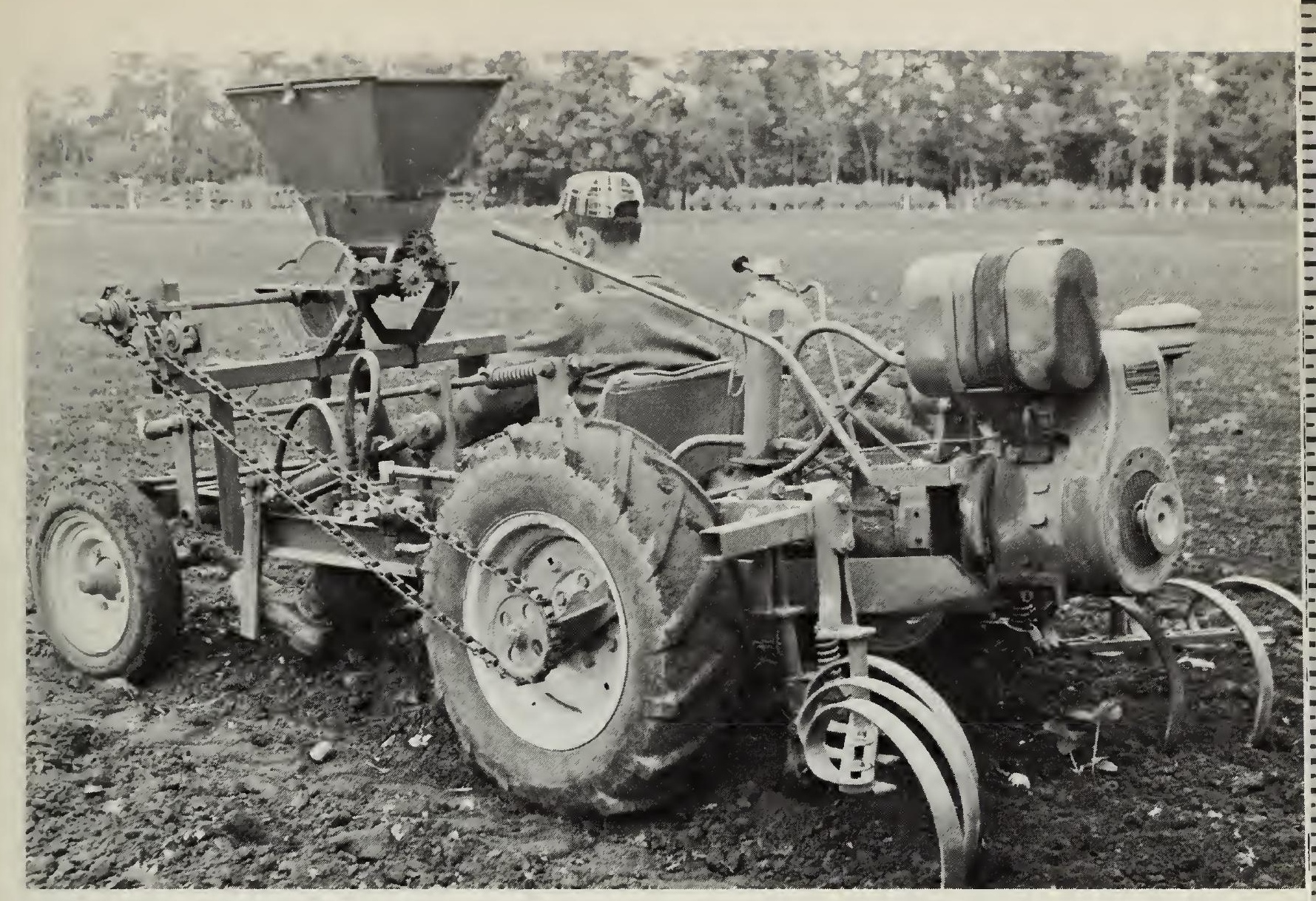

Fig. 6 A self-propelled cultivator is guided by your feet, leaving your hands free to operate a pair of

wiggle hoes. Fertilizer can also be applied with this machine.

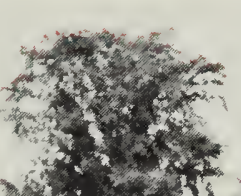
$x^{3}+x^{2}-x^{2}+3 k$ anstion

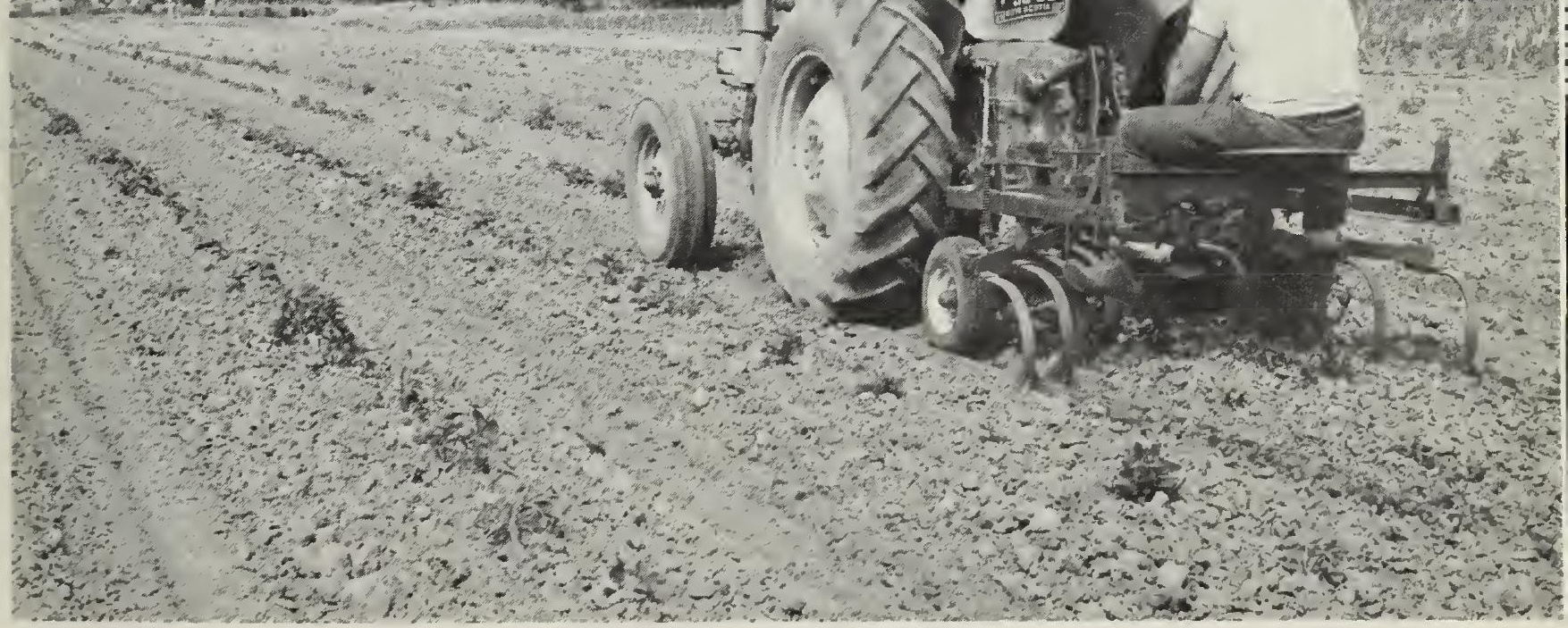


Most commercial strawberry growers in Eastern Canada need an irrigation system. Extra moisture is usually required either at planting time. during the harvest season, during runner development and rooting, or at the time of renovation. Some growers also find irrigation useful for preventing frost damage to flowers and for applying fertilizers.

Irrigation of newly set plants firms the soil around the roots and helps them to establish quickly. Plants well supplied with moisture begin to runner and establish their root systems early. Plants formed early in the season are more productive than those formed later.

Soil moisture has a very significant effect on fruit size and yield. Established strawberry plants have $75 \%$ of their roots in the top $7.6 \mathrm{~cm} / 3 \mathrm{in}$.) of soil and $90 \%$ in the top $15 \mathrm{~cm}$ ( $6 \mathrm{in}$.). Between 2.5 and $3.8 \mathrm{~cm} / 1$ and 1.5 in.) of water each week is required to supply enough moisture during the fruiting season. If this does not fall as rain, it should be supplied by irrigation. Weekly rainfalls of less than $1.2 \mathrm{~cm}(.5 \mathrm{in}$.) are of no consequence and should not be included in the amount of total rainfall, especially during hot weather.

Start irrigation before the plants begin to wilt. A soil test is the easiest method of determining the amount of water that is needed. Since available soil water must be more than $50 \%$ for continued plant growth, start irrigation before the soil reaches this point. Use Table 1 as a guide for determining soil moisture levels. It is based on the feel of the soil when squeezed into a ball. If the soil sample taken from the root zone does not hold together when squeezed, start irrigation. Simple instruments for measuring soil moisture are also available. Insert the instrument in the soil in a permanent position. The soil moisture content shows on a dial gauge.

Excessive irrigation during the fruiting season may result in soft fruit that is unfit for the fresh market. Soil nutrients may also be leached from the root zone and chances of fruit rot are increased if a rigid fungicide program is not followed. Use enough water to bring the available moisture in the top $31 \mathrm{~cm}$ (12 in.) of soil to $100 \%$.

For further information concerning irrigation and for assistance in designing irrigation systems, consult your provincial agricultural specialist.

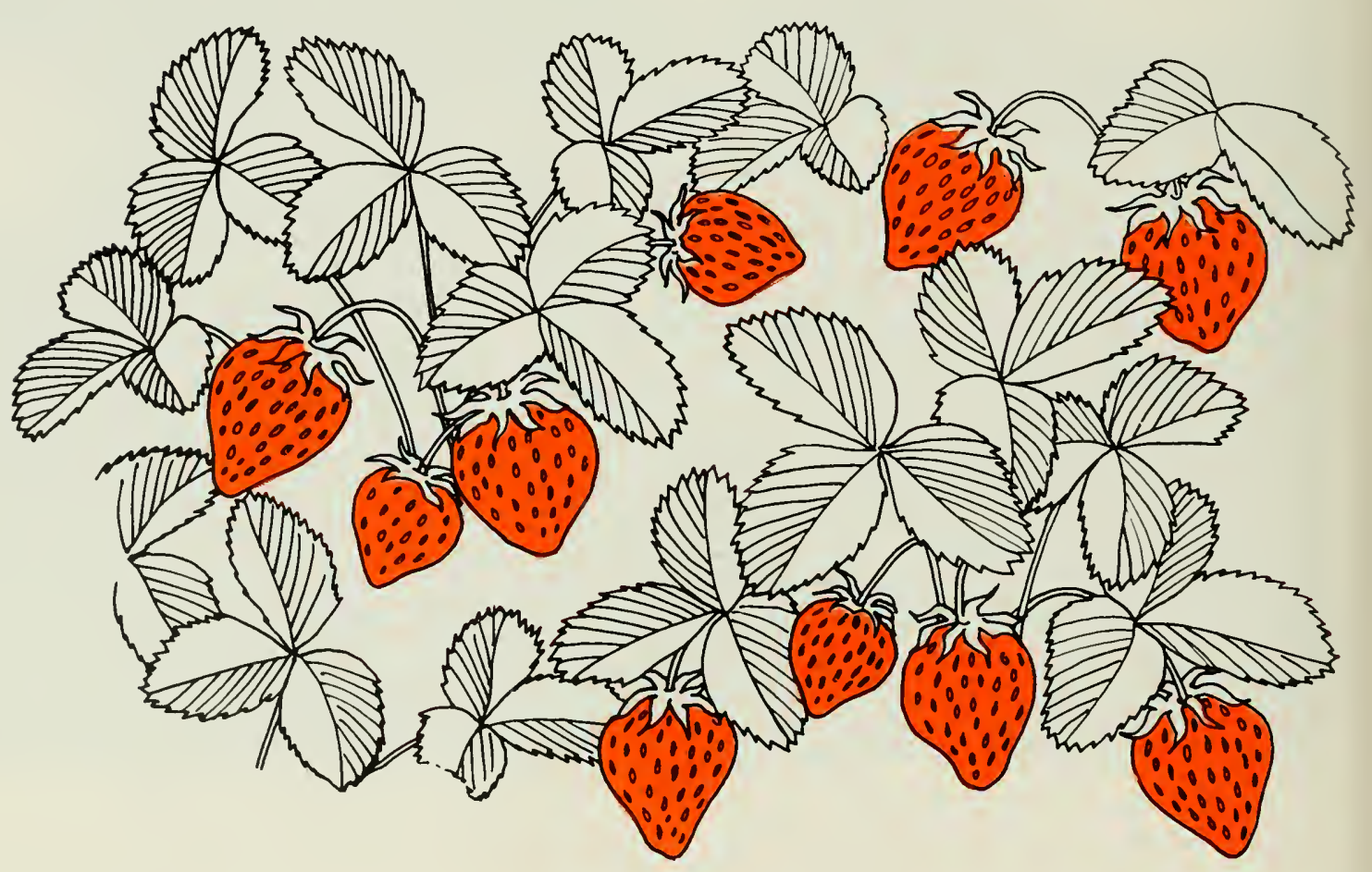




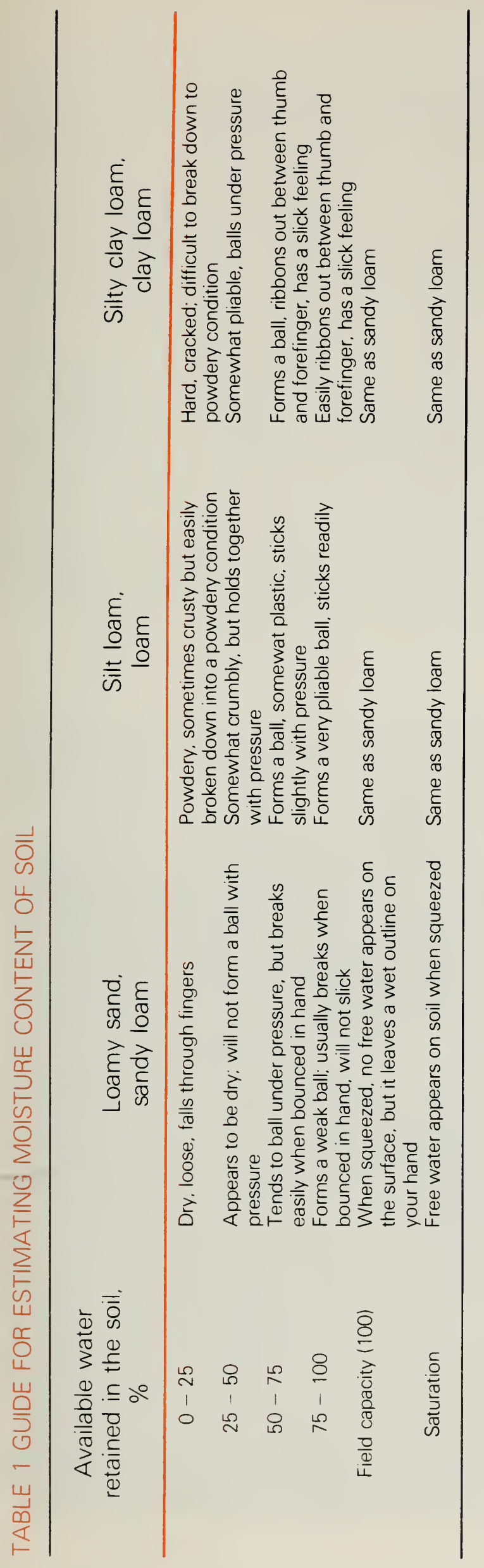




\section{MULCHING}

Strawberry plants must be mulched to prevent winter damage. If plants are unprotected, low winter temperatures injure roots, fruit buds, and other crown tissues. Alternate freezing and thawing of the soil may heave the plants and break the roots. Plants with damaged root systems lack moisture during the harvest period.

Oats, wheat, and rye straw are ideal for mulch. Some straw contains grain that is likely to grow and become troublesome in the spring. For this reason, old straw is best. Do not use old hay because it usually contains too many weed seeds. Apply a herbicide before mulching to control germinating grain and weed seeds.

When to apply the mulch is important! Spreading the mulch early, before the plants have become fully dormant, may cause severe damage to leaves and crown. It is best to apply the mulch after the first hard freeze, which, depending on your loation in Eastern Canada, is between midNovember and early December. A light frost will not hurt the plants, but they should be protected when temperatures drop to $-9.4^{\circ}$ to $-7.8^{\circ} \mathrm{C}\left(15^{\circ}\right.$ to $\left.18^{\circ} \mathrm{F}\right)$. Experiments have shown that a temperature of $-6.7^{\circ} \mathrm{C}\left(20^{\circ} \mathrm{F}\right)$ injures the crown and causes internal browning. The exact temperature at which injury will occur varies for each plant. The older, larger plants are less likely to be injured than the younger, weaker plants. Many diseases such as black root

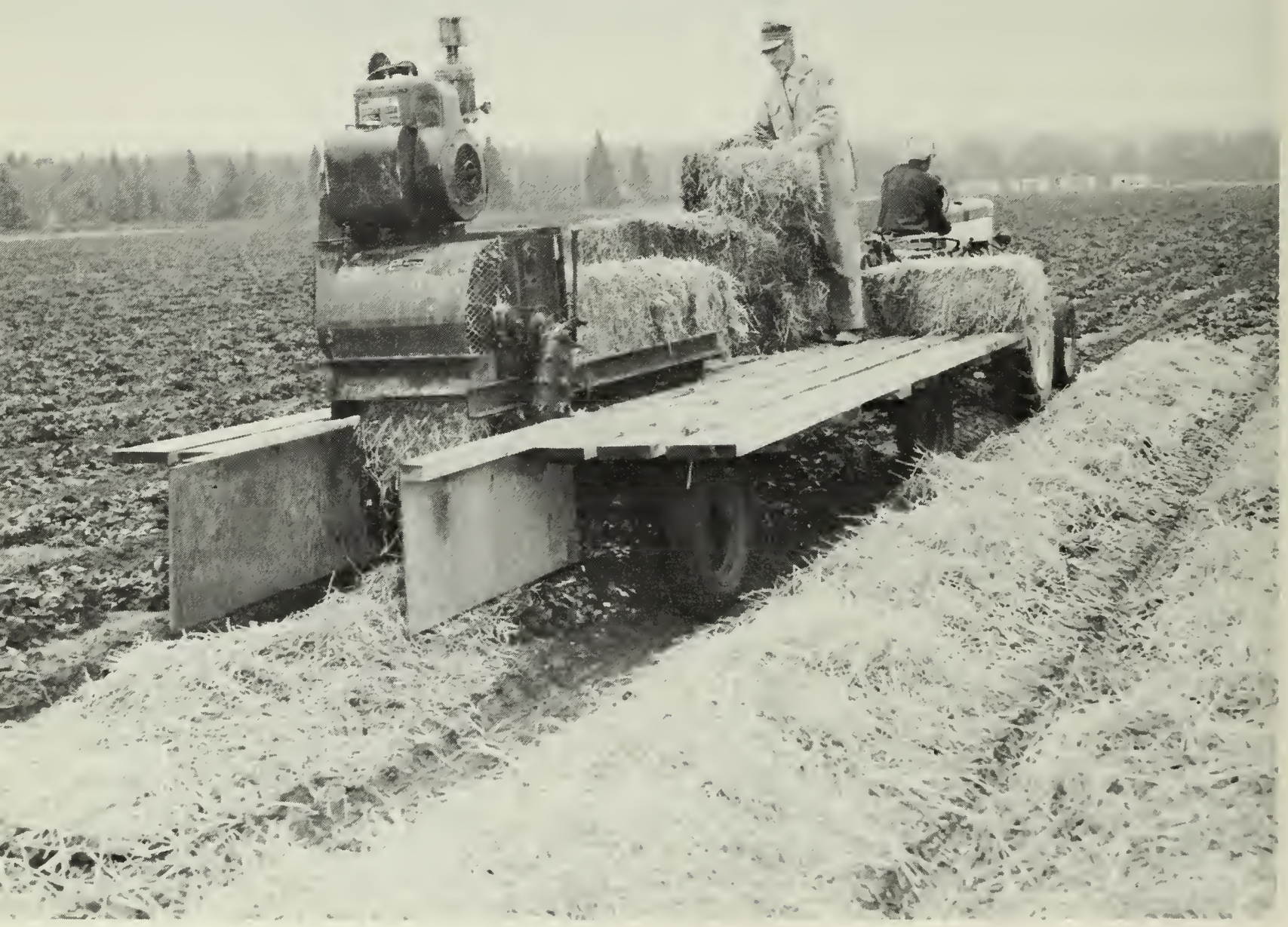


and root rot of strawberries start after the plants have been weakened by winter injury.

The mulch should be spread uniformly over the field (Fig. 8). The thickness of the mulch should be governed by the type of soil. Clay soils tend to heave because of frost and therefore they need a thicker mulch than light soils. Usually a mulch about $5 \mathrm{~cm}(2 \mathrm{in}$.) thick when settled gives ample protection. This requires about 6.7 tonnes of straw per hectare ( 3 tons / ac).

Remove the mulch from your plants in the spring when new leaves start to grow and the foliage begins to get light yellow; leave from one-third to one-half of the mulch over the bed for the plants to grow up through (Fig. 9). This mulch helps to control weeds and keeps the fruit clean during harvest. Keep the excess mulch in the row aisles. It can be used to recover the plants if frost threatens. It also provides a clean kneeling area for the pickers at harvest time. Do not remove the mulch too early in the spring, because it delays blossoming and thus gives some protection against a late spring frost. A mulched field is usually more susceptible to frosts during blossoming than one that is not mulched, because bare soil holds more soil heat.

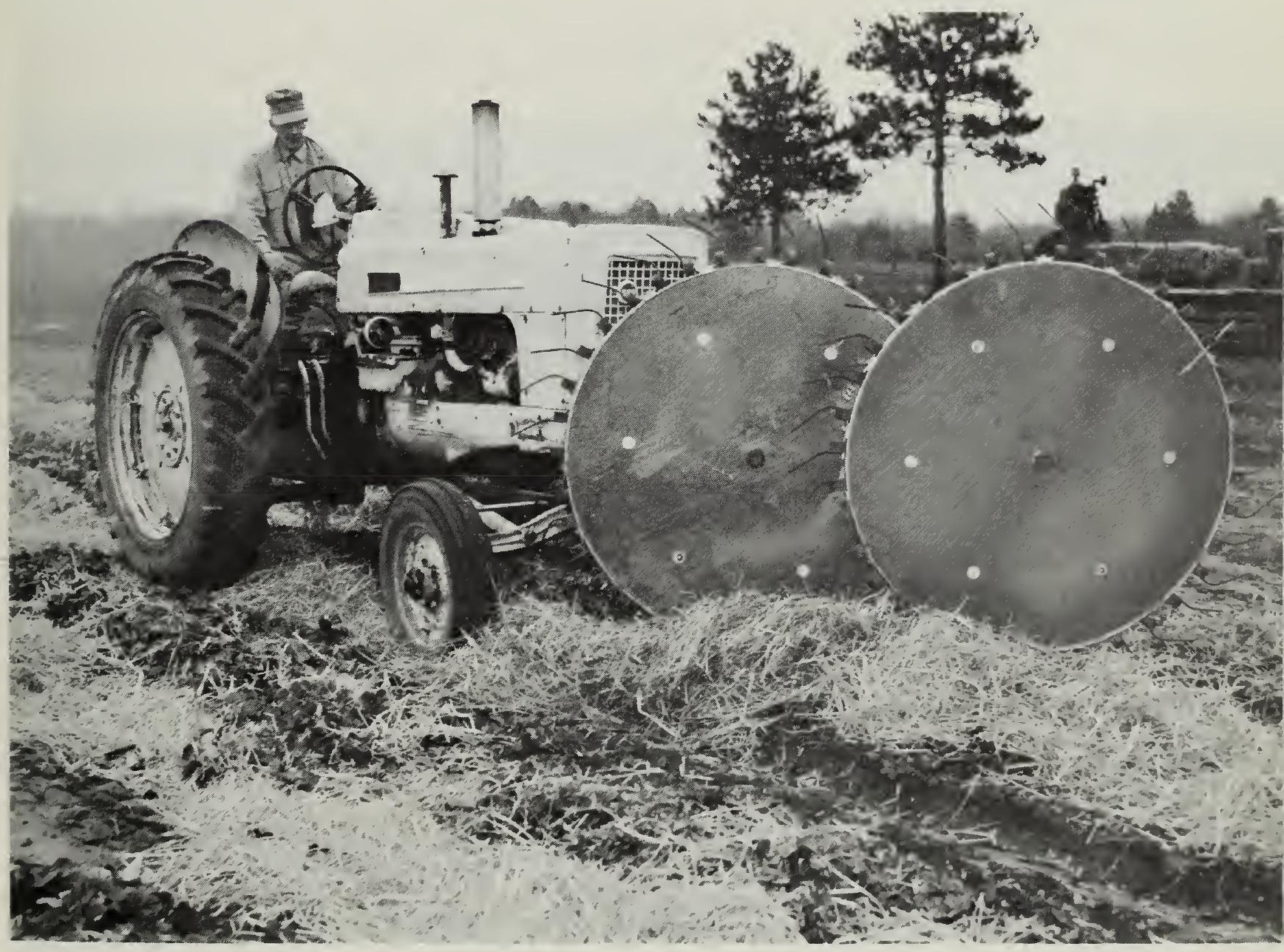

Fig 9 A rig to remove the straw from the plants 


\section{FROST INJURY}

Frost often occurs when strawberries are in bloom. Temperatures of $-1.1^{\circ} \mathrm{C}\left(30^{\circ} \mathrm{F}\right)$ at plant level only slightly injure open flowers, whereas severe injury occurs at $-3.3^{\circ} \mathrm{C}\left(26^{\circ} \mathrm{F}\right)$. Buds and developing berries may also be injured at this temperature.

Frost usually injures only the flower pistils, which turn black (Fig. 10): injury to the pistils prevents pollination. Flowers in which a few pistils have been damaged produce misshapen berries (Fig. 11) that are of little commercial value.

Frost rarely causes a complete crop loss, because strawberries produce flowers for about 2 weeks or longer. The first flowers to open are the ones most likely to be injured, which is unfortunate, because they normally develop into the largest berries.

Protect blossoms with sprinkle irrigation when temperatures drop as low as $-6.7^{\circ} \mathrm{C}\left(20^{\circ} \mathrm{F}\right)$. Use special frost nozzles, which deliver water at about 2.5 $\mathrm{mm} / 1 / 10 \mathrm{in}$.) per hour. Begin sprinkling just before the air temperature at soil level reaches $-0.6^{\circ} \mathrm{C}\left(31^{\circ} \mathrm{F}\right)$. Continue until the temperature has risen enough to melt all the ice that has formed. The conversion of water to ice on the plants releases heat and counteracts the low air temperature. To maintain the safety margin, water must be continually freezing on the plant. This is the reason for continuing sprinkling for as long as ice forms.

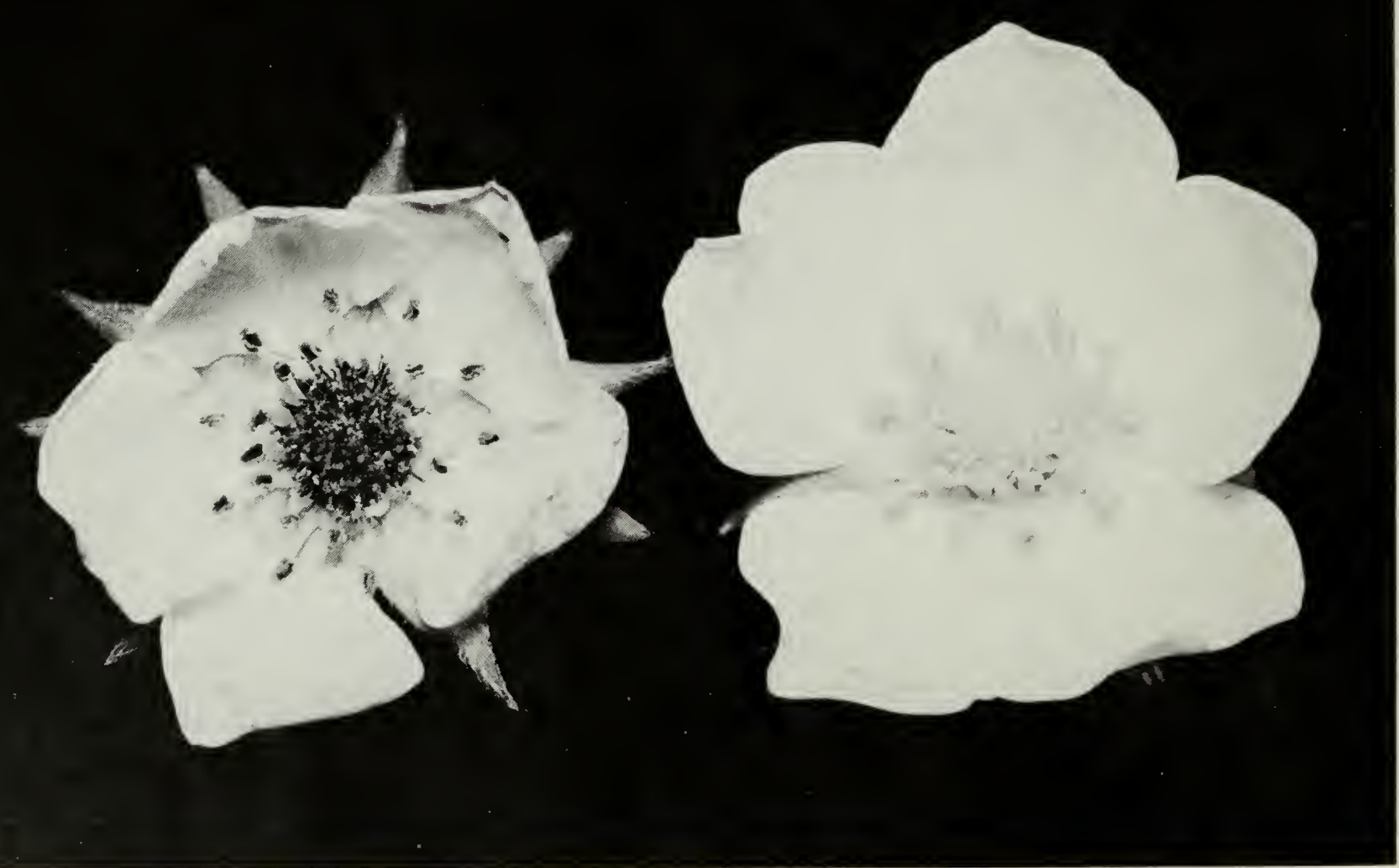

Fig. 10 Frost has killed the pistils and stamens on the left flower, the right flower is unınjured. 


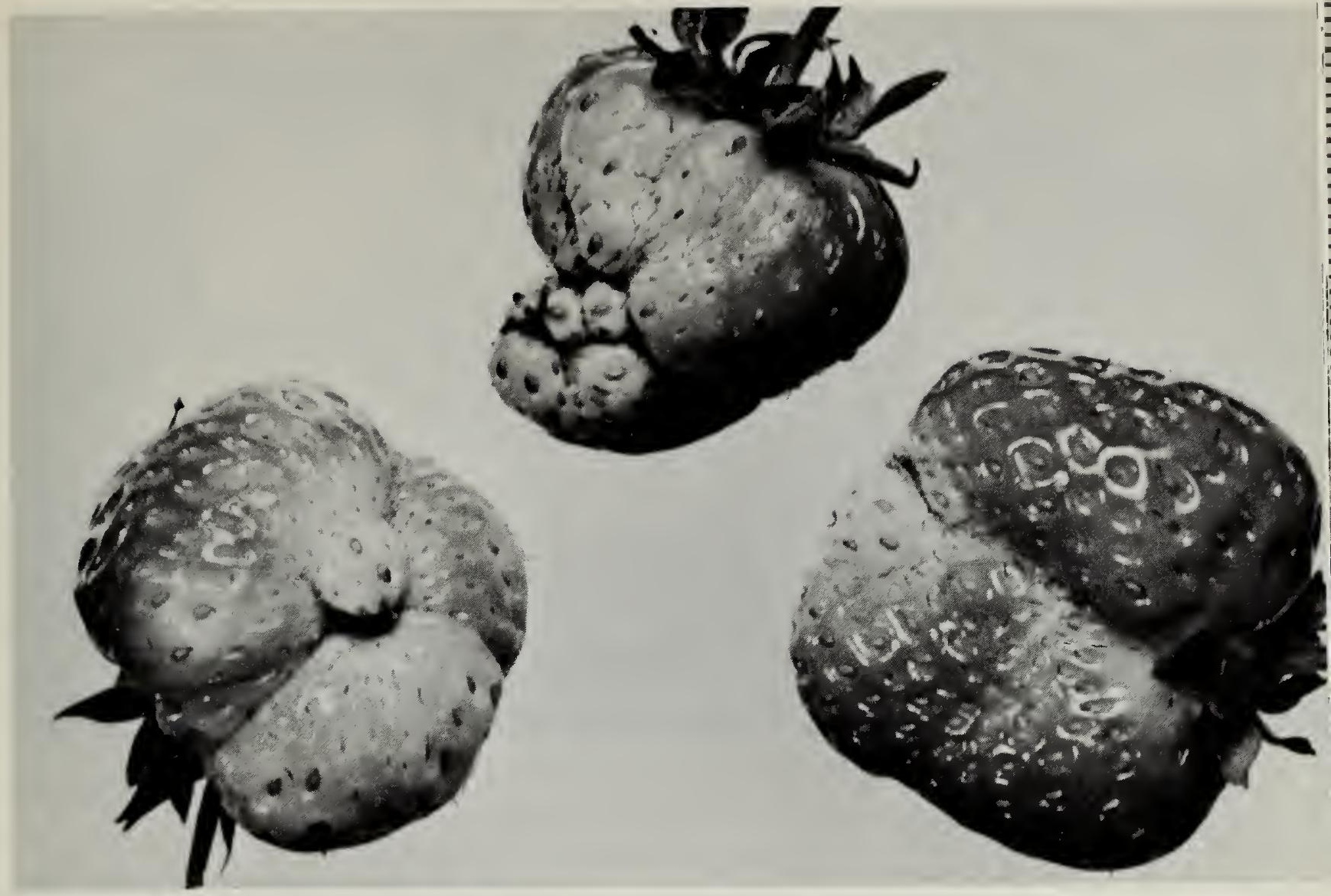

Fig. 11 Lack of proper pollination causes misshapen fruit.

\section{POLLINATION AND MISSHAPEN BERRIES}

Maximum yields and fruit size are obtained when there are adequate pollinating insects in the strawberry field. Strawberries will set fruit when insects are excluded but the berries will be small and often malformed (Fig. 11).

Some varieties fail to produce well-formed stamens (Fig. 12) during cool weather. This is especially true of the primary flowers. The stamens contain the pollen necessary to bring about fertilization and fruit set. When pollen is not abundant, it is necessary to have large numbers of pollinating insects.

Strawberry growers in Eastern Canada apply insecticides at the fullbloom stage for control of weevils and mirids (plant bugs). These insecticides are toxic to the pollinating insects. Take great care in the timing of spraying. Do not spray during the daylight hours when the pollinating insects are active in your strawberry field. Spray in the evening when insect activity is at a minimum. Provide colonies of honey bees for the pollination of strawberry plants if the number of native bees is low. 


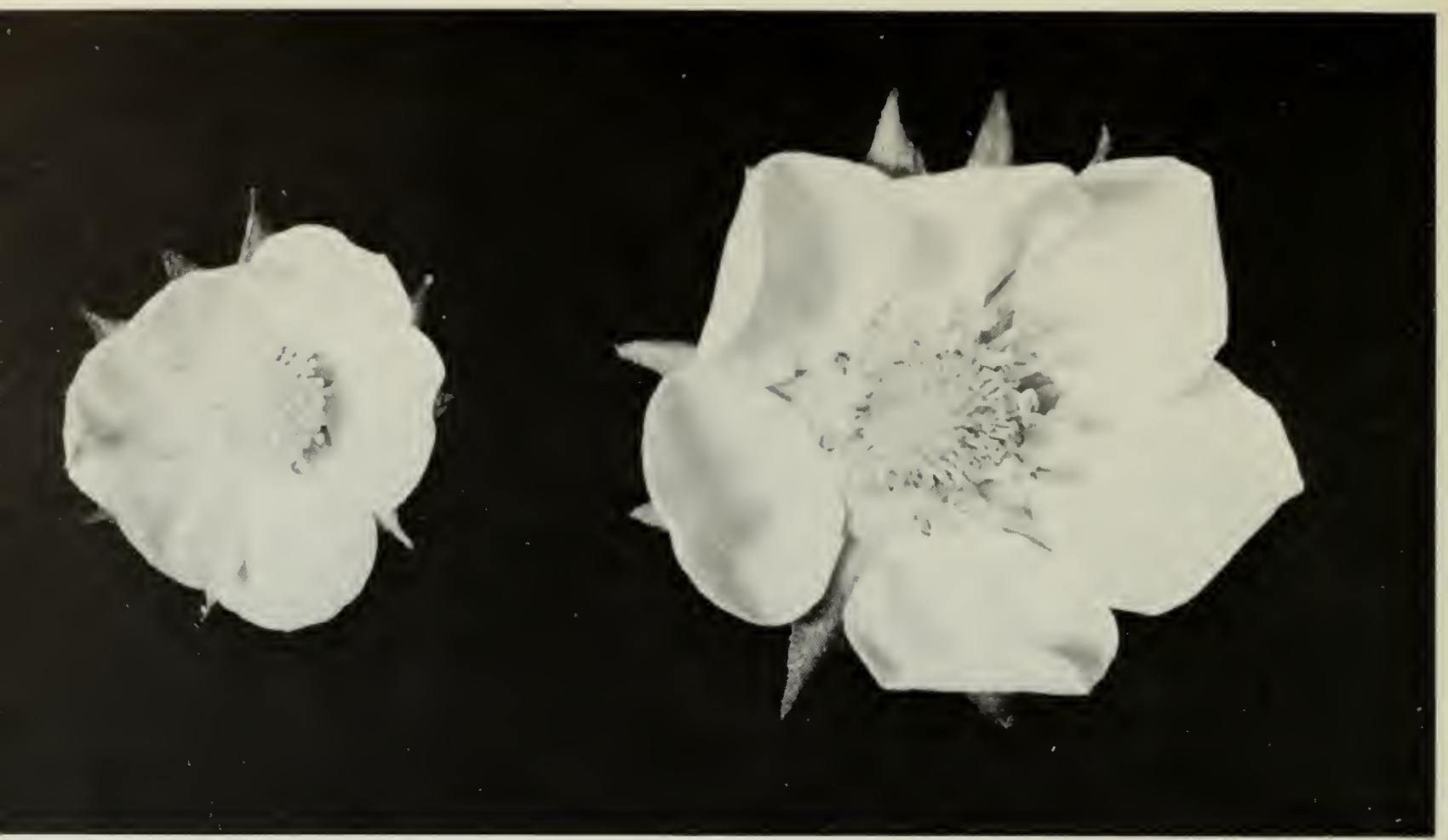

Fig. 12 The left flower has no stamens so it cannot produce pollen. The right flower is normal its stamens and pistils are well developed.

\section{HARVESTING AND HANDLING}

\section{PICKING}

It is important to have pickers available and engaged before the harvest period. From 15 to 25 pickers per hectare are required, depending on their experience, the size of the crop, and the rate at which berries are ripening. Berries for the fresh market are generally picked every second day. However, in cool or hot weather the rate of ripening can change, resulting in picking every 3 to 4 days, or every day. When berries are plentiful, it is easy to keep good pickers.

Pick fresh fruit for local markets and for processing when the berries are completely red. Harvest fruit for shipping to distant markets when the berries are partly colored.

When harvesting for fresh fruit, grasp the stem just above the berry with your thumb and forefinger and pull with a slight twisting motion (Fig. 13). This will break the stem about $1.3 \mathrm{~cm}(1 / 2 \mathrm{in}$.) from the berry. Allow the first fruit to roll into the palm of your hand and pick another one using your thumb and forefinger as before. Repeat these operations using both hands at the same time. To avoid crushing the berries, only hold two or three in your hand at one time. Place these berries in the boxes and repeat the picking process.

Provide your pickers with a carrying tray or flat, which holds 6 to 12 boxes. The pickers take these trays or flats into the field where they fill the boxes. When the trays are full, the pickers carry them to the packing station and receive credit for the number of boxes they have filled. Pickers are usually paid by the box.

Arrange to have cold drinking water and comfort stations available for the pickers at or near the strawberry field. 


\section{SUPERVISING}

Proper supervision of the entire harvest operation is necessary in order to prepare and market a quality product. This includes supervision of all aspects of the harvest picking, field handling, packing, and transporting to the market or cooler. You need one field supervisor for each group of 10 to 20 pickers.

\section{GRADING}

Some growers grade the fruit at picking time. The large fruit is placed in a separate box from the small or misshapen fruit. To retain a high quality in packing, place the berries on the top of the box with the side or end turned up. Grading can also be carried out in packing sheds or on belts, where the highest quality fruit can be repacked for sale on the fresh market. Keep grading to a minimum, because extra handling increases bruising.

\section{FIELD SHELTERS}

Packing shelters are needed to protect the fruit from direct sunlight and may be used when you are filling trays or crates before shipping the berries to market or storage cooler. Several shelters are needed for large plantings. Mobile shelters may also be used. Locate the shelters close to the pickers so they do not have to walk far to the packing shelter, which saves time and increases their harvest rate.

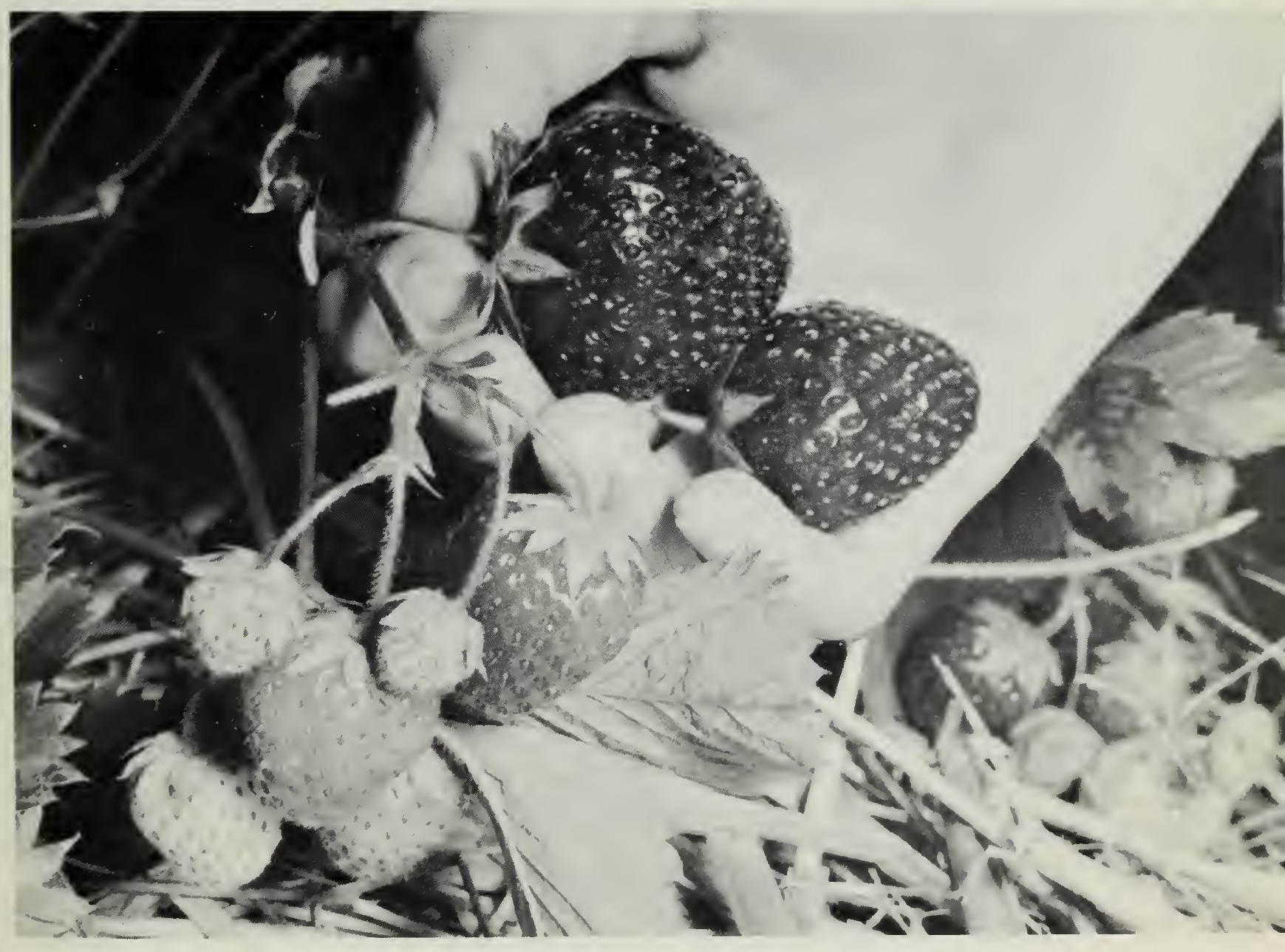

Fig. 13 When pickıng berries for the fresh market, pinch and iwist the stem then let the fruit roll into the palm of your hand. Do not pull the fruit off 


\section{CONTAINERS}

In Eastern Canada, strawberries are usually sold on the fresh market in quart $(1102 \mathrm{ml})$ boxes. These boxes are made from veneer, plastic, or fiberboard. Trays for holding the boxes may be made of wood or cardboard. Fruit for processing is packed in 8-quart (8816-ml) wooden or plastic trays and in quart (1102 $\mathrm{ml})$ boxes.

\section{MECHANICAL PICKING AIDS}

Strawberries can be harvested with the aid of a machine that carries 6 to 10 pickers in a prone position and travels slowly through the field. Generally, the pickers on these machines will work longer hours, earn more money, and spend less time traveling to field shelters than the conventional pickers. Fewer pickers are required, supervision of pickers is simplified, berries can be kept in the shade continuously, and the fruit along the sides of rows does not get crushed.

\section{MECHANICAL HARVESTERS}

Machines that remove all of the foliage and all of the fruit in a once-over operation have been developed. They are not yet in use commercially in Canada, but they are being evaluated. It is too early to determine if they will be useful to growers in Eastern Canada for harvesting fruit for the fresh market or only for processing.

\section{PRECOOLING}

Strawberries deteriorate rapidly at warm temperatures because of normal chemical changes and because of fungus diseases, such as gray mold and leak. Rapid cooling to about $0^{\circ} \mathrm{C}\left(32^{\circ} \mathrm{F}\right)$ slows down these changes. Berries for export and local sales must be precooled (Fig. 14) and shipped in refrigerated trucks.

Immediately after they have been picked, move the berries to a cooler at $0^{\circ} \mathrm{C}\left(32^{\circ} \mathrm{F}\right)$. When strawberries are first placed in the cooler, they still contain field heat and they continue producing heat because of respiration. Therefore, stacking the fruit in a refrigerated room is not adequate. Berries in the boxes in the center of the stock may take up to 36 hours to lose 5.5 to 11 degrees $C$ (10 to 20 degrees F). To reduce the cooling time, blow cold air over and through the fruit. This procedure is called forced-air precooling. The refrigeration requirements for this rapid heat removal are much higher than for a holding storage. Ask an agricultural engineer for advice on how to determine the refrigeration capacity suitable for the size of your operation. The refrigeration system must be big enough to cool the berries to the desired temperature in 2 to 6 hours. Experience has shown that air movement through the berries should be $0.0007 \mathrm{~m} 3 / \mathrm{s}(1.5 \mathrm{cfm})$ of air per $453.6 \mathrm{~g}(1 \mathrm{lb})$ of fruit.

Commercial refrigerated storages can be used for precooling strawberries by the addition of special fans that circulate the air. If necessary, strawberries that are free of disease can be held in storage for 10 days at $-0.6^{\circ} \mathrm{C}\left(31^{\circ} \mathrm{F}\right)$ and about $90 \%$ relative humidity.

\section{PICK-YOUR-OWN}

A fairly new harvesting and marketing idea, the pick-your-own system, has sparked a new interest in strawberry growing in Eastern Canada. Many strawberry growers are taking advantage of this system of selling to increase 


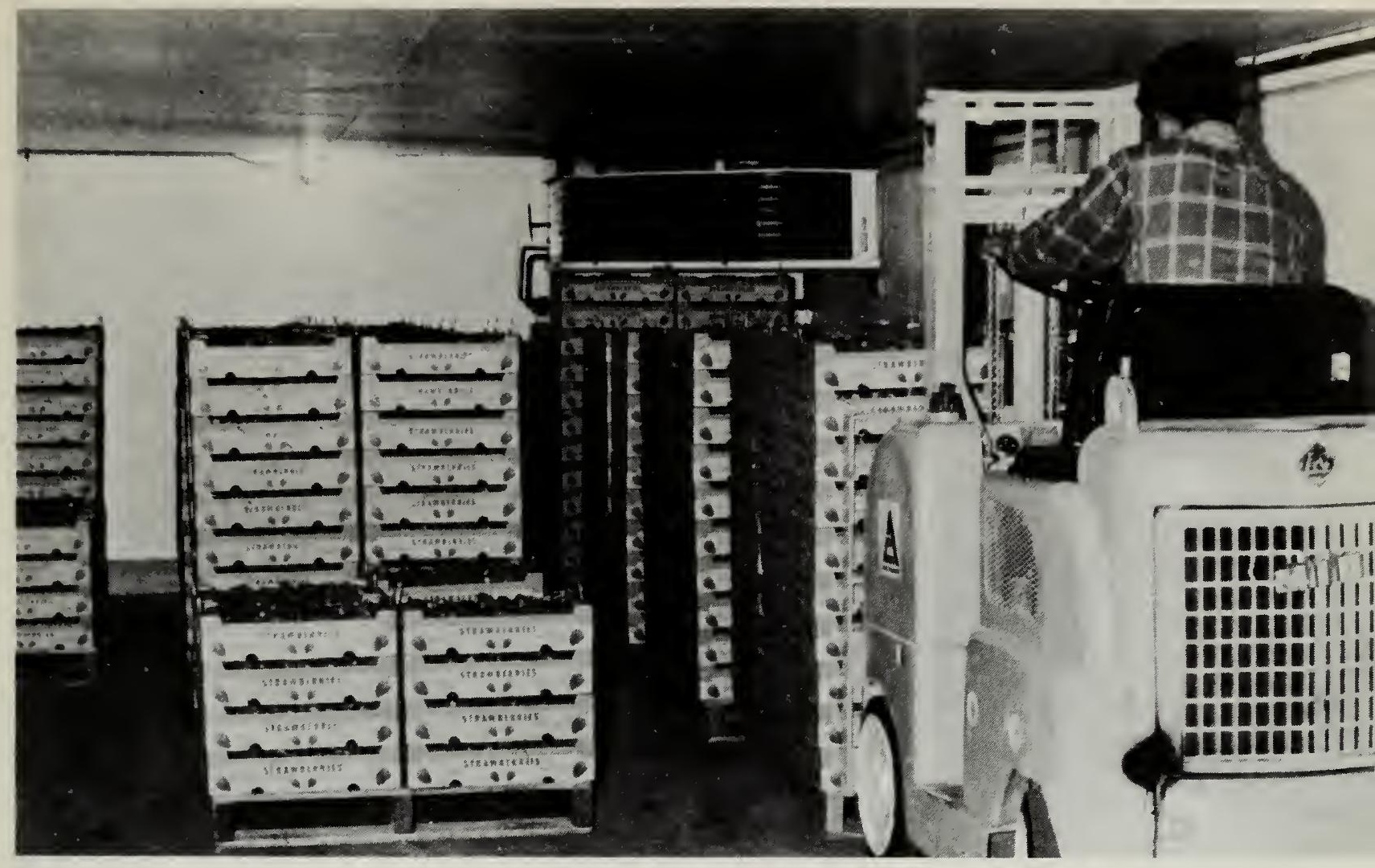

Fig. 14 A well-constructed cooler and proper equipment for handling are essential for keeping fruit in prime condition

their income. This method of direct selling provides farm-fresh, high-quality strawberries at lower prices to customers who pick their own berries.

The following trends seem to make the pick-your-own system an attractive marketing opportunity:

- Customers want high-quality strawberries.

- A shortage of suitable harvest labor has encouraged many growers to try this system.

- Customers will pick the amount of berries they require if the price is fair.

- The net profits may be higher from the pick-your-own system because of rising costs of labor, packaging, and selling through present marketing systems.

There are many advantages to pick-your-own, both for the grower and the customer.

Some of the advantages for the growers include:

- The need for seasonal labor is reduced.

- Sorting, packing, and storing are eliminated.

- Many customers provide their own boxes or they will accept less expensive containers than wholesale shipment requires.

- The money comes in as soon as the crop is harvested without the risk of price changes, and no commissions have to be paid.

- Impulse buying is increased.

For the customers, there are also advantages:

- Customers like to harvest their own produce. It gives them an opportunity to buy fully ripened, farm-fresh produce in quantities for canning or freezing and at prices lower than they would pay elsewhere.

- An increasing proportion of the population lives in urban areas. A farm outing for these people is usually so psychologically rewarding that time, distance, inconvenience, and cost seem insignificant. 
All growers are not equally suited to provide pick-your-own selling operations. The grower and his employees must show a friendly attitude and personality toward the public. A pleasant manner is a real asset. The grower should not make his customer feel he is doing them a favor by allowing them to pick-their-own produce.

Also, the grower must advertise to let the public know when the crop is ready, the hours when the planting is open for picking, and the directions for getting there. Provide ample parking space and a play area for children. Supervisors must be available to organize the picking, and an efficient checking out and payment system must be set up. Picking containers, drinking water, and toilet facilities are also needed.

\section{RENOVATING}

Strawberry plantings should produce more than one crop. It costs less to renew a planting than to establish a new one. The second crop may be as large or larger than the first. It is possible to get more than two good crops from a planting. The main requirement is a good stand of healthy vigorous plants. A certain number of broadleaf weeds is not a problem, because they can be eliminated with chemicals. Grasses such as quack grass cannot be controlled with chemicals. When grasses take over the planting, it is not usually economical to renovate.

Strawberry plants tend to stop growing as soon as the berries are picked. Leaf, runner, and root development is greatly reduced. To prevent this, start renovating the day after picking is finished. Stimulate the plants to start them growing again.

Follow these steps to renovate your planting:

- Mow off the foliage immediately after harvest. Do not mow later in the season.

- Apply fertilizer before you mow the plants to avoid burning them. Consult your agricultural representative for the amounts and kinds of fertilizer to use in your province.

- Rake the unrooted runners into the aisles; where they can be cut off when you narrow the rows.

- Narrow both sides of the row (Fig. 15) if the planting is going to produce only a second crop. After a second crop, narrow from one side only, in order to remove the plants used to establish the planting. Plants 3 years old and older produce less fruit than well-established young runner plants.

- Keep a space 18 to $23 \mathrm{~cm}$ (6 to $9 \mathrm{in}$.) between plants in the row. Draw a double section spike-tooth harrow across the field several times in different directions to obtain the desired plant stand and to remove weak plants.

- Irrigate immediately after renovation if the soil is dry.

\section{EVERBEARING STRAWBERRIES}

Everbearing strawberries differ from June-bearing varieties by forming fruit buds in the long warm days of summer and producing a fall crop. They also produce a spring crop from flowers formed the previous fall, just as the June-bearing varieties do.

Everbearing strawberries are of some value for home gardens, but have not been very successful commercially in Eastern Canada. They need a lot of handwork, their picking costs are high, and yields are often unsatisfactory. In some areas, cold weather prevents much of the crop from maturing. Plant 


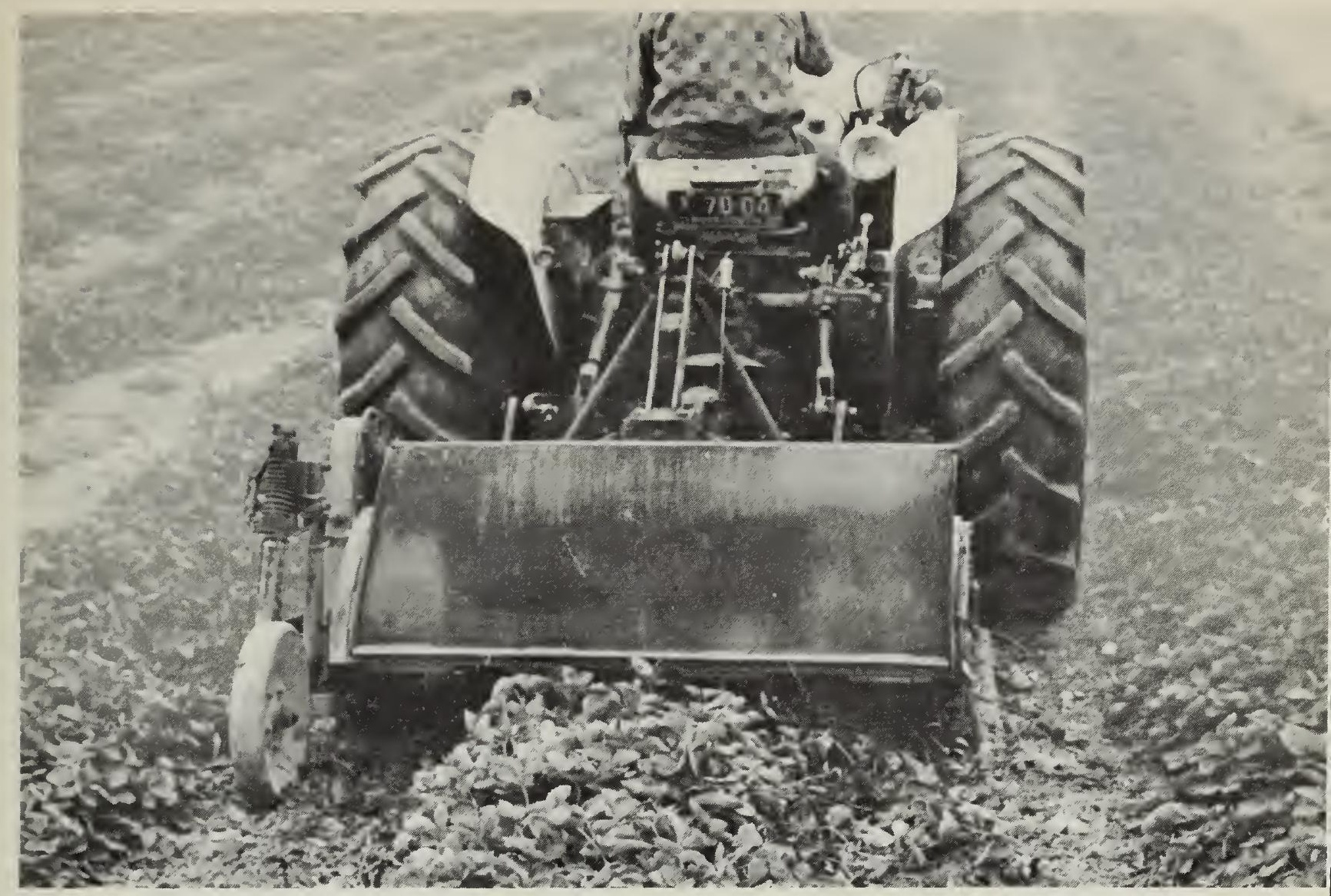

Fig. 15 Renovating the field with a rotary-type tiller.

bugs are often abundant when the plants are flowering and, unless you use an insecticide regularly, the pests will cause malformed fruit. To avoid a residue from the insecticide, select one that is short lived. Herbicides are of limited value because of potential residue problems.

Most everbearing varieties do not runner well so they are best grown in the hill system. Set out the plants in single rows or in beds of two, three, or four rows with a walkway between the beds. Space the plants in beds about $0.3 \mathrm{~m}(1 \mathrm{ft}$ ) apart each way. Use sawdust or black plastic as a mulch to control weeds and to keep the fruit clean. If you use the hill system, remove runner plants as they appear.

Everbearers need well-prepared soil, rich in organic matter. Set out the plants in the spring and remove all blossoms until mid-July. From then on leave all blossoms to develop. Side-dressings of fertilizers may be required. Irrigation is usually needed, because the plants are fruiting during the warmest and driest part of the growing season. Consult your local agricultural office for varieties best suited to your province.

\section{STRAWBERRY PESTS}

A number of pests attack strawberries. Check your plantation regularly for signs of injury. Loss from pests occurs particularly during the blossom period, when weevils or plant bugs can destroy a potential crop in a few days. Inspect the field thoroughly and apply sprays if necessary.

For control measures, check the current protection guide available from your agricultural representative. 


\section{PESTS THAT ATTACK ROOTS}

ROOT WEEVILS - Three species of root weevils attack strawberries in Eastern Canada, but only rarely are they sufficiently numerous to require control measures. The adult root weevil (Fig. 16) is a hard-shelled beetle with a short snout and it cannot fly. The larvae (see also Fig. 16) are up to $1.3 \mathrm{~cm}$ $(1 / 2$ in.) long. white or pinkish with brown heads, and legless. They usually attack strawberry roots. The larvae change to pupae in the soil.

WHITE GRUBS - White grubs (Fig. 17). 2 to $4 \mathrm{~cm}(0.8$ to $1.6 \mathrm{in}$.) long. are the larvae of June beetles. They are occasionally numerous in fields cultivated for a strawberry plantation. They are more common on land that was in sod the previous year. The individual grub feeds on the roots of a strawberry plant, usually killing it. Dig up any dead plants that you find in your field and examine them for the presence of this large whitish grub, which is usually tightly curled.

NEMATODES - Many species of these tiny wormlike animals live in the soil. The harmful species cause lesions on the roots. When the lesions are numerous, areas of the root may turn black and many of the lateral roots die. Absorption of nutrients and water is reduced, resulting in poor plant growth. The root lesions are also places of entry for fungi that cause black rot and verticillium wilt. Fumigants are helpful in controlling nematodes.

\section{PESTS THAT ATTACK LEAVES, BLOSSOMS, OR FRUIT}

STRAWBERRY WEEVIL - This is the most common pest of strawberries and usually requires control measures every year. It is a dark brown weevil, 2 to $3 \mathrm{~mm}(0.08$ to $0.12 \mathrm{in}$.) long, with light spots and a long snout. It cuts the stems of blossoms in early spring, when the first blossoms open. The eggs are laid in the blossom before it is cut, and the larva matures in the cut bud. The adult strawberry weevil (Fig. 18) chews holes in the petals, which are often more conspicuous than the blossom stem stubs. The petal holes are symptoms of the weevil's presence. Only one generation occurs each year. therefore one pesticide application usually controls the pest for the season.

PLANT BUGS - Plant bugs (Fig. 19) are often very destructive in fruiting plantations. The young nymphs of tarnished plant bugs or of the strawberry capsid, Calocoris norvegicus Gmel., have sucking mouthparts for feeding on the fruit as it starts to grow. These areas become hard resulting in a deformed nubbin. The green nymph of plant bugs is so small when first hatched that it is hard to see. If you place the nymph on a dark surface or hold it in your hand. you can usually see it and identify it by its rapid running. Most other insects at that time of the season move slowly. Plant bugs can completely ruin a crop if control measures are not taken. Because their populations vary from place to place each year, carefully check each plantation as soon as the first blossoms appear and take control measures if necessary. A second treatment may be needed if nymphs continue to emerge.

TWOSPOTTED SPIDER MITE - The twospotted spider mite (Fig. 20) is not a serious pest in most areas. It is usually kept in check by predators. Outbreaks occur where predators are removed by broad-spectrum sprays.

Feeding and egg laying occur on the underside of the leaves where webbing is common on heavier infestations. The leaves change color becoming bronzed from the effects of feeding. Several generations occur in a season, and all stages may be found from midseason until fall. The mite overwinters in the mature adult stage and begins laying eggs in early spring. 
CYCLAMEN MITE - This is a very small mite and even the adult is very difficult to see without magnification. The cyclamen mite (Fig. 21) is also subject to predation and is only occasionally a problem. It feeds on the unfolding leaves and blossoms and causes distortion and stunting.

STRAWBERRY LEAFROLLER - The larvae of this pest feed on foliage and usually tie leaves together with a fine webbing. In most areas the strawberry leafroller (Fig. 22) does not reach numbers requiring control measures.

LEAFHOPPERS - Various species of leafhoppers (Fig. 23) feed on strawberry foliage and in large numbers, they may cause injury. The sixspotted leafhopper transmits the green petal virus disease of strawberry. Control infestations with an insecticide.

APHIDS - Several species of aphids (Fig. 24) are found on the undersides and stems of strawberry leaves. They are small, soft-bodied, and usually greenish or yellowish. They seldom cause much direct injury, but some species are very important because they transmit virus diseases.

SLUGS - Slugs (Fig. 25) are slimy, legless animals that eat holes in ripening berries, particularly during damp weather. They can be destructive if present in large numbers.

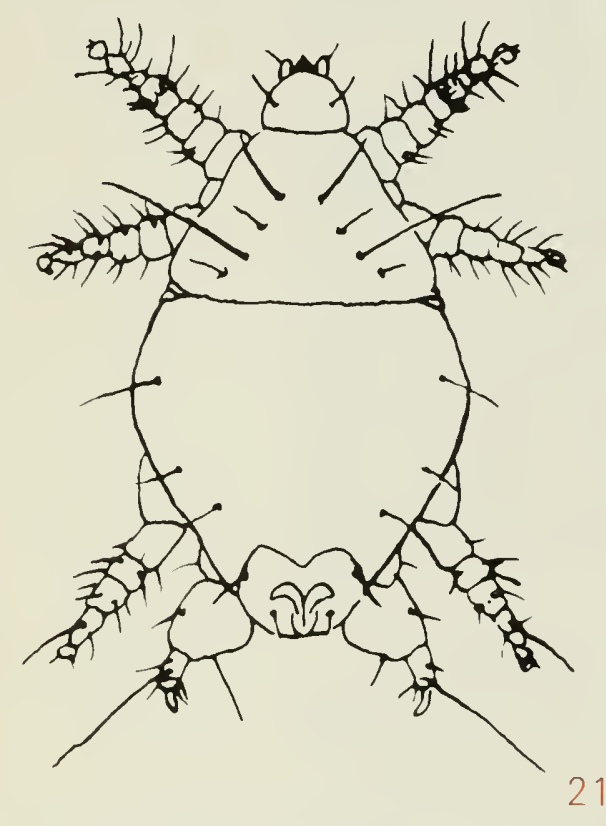

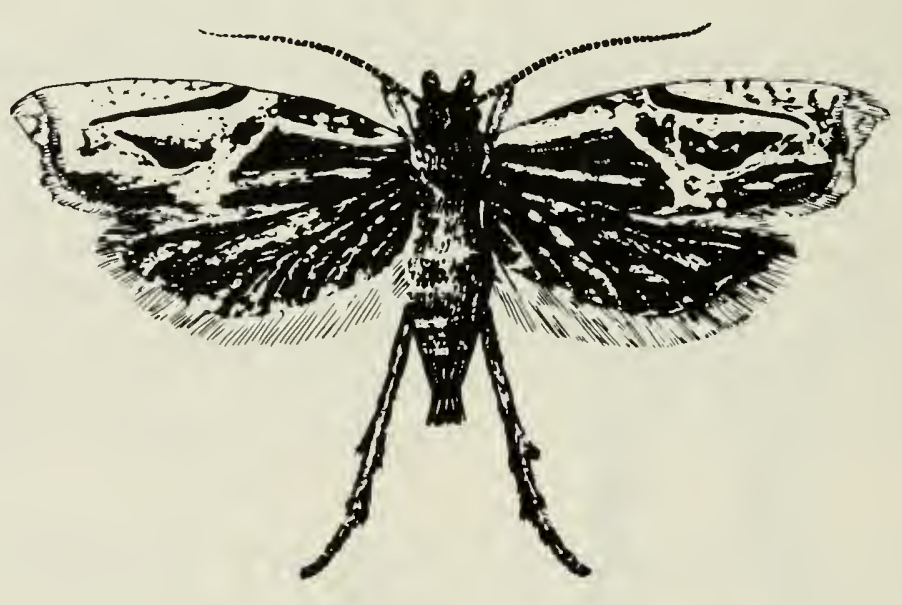

22 


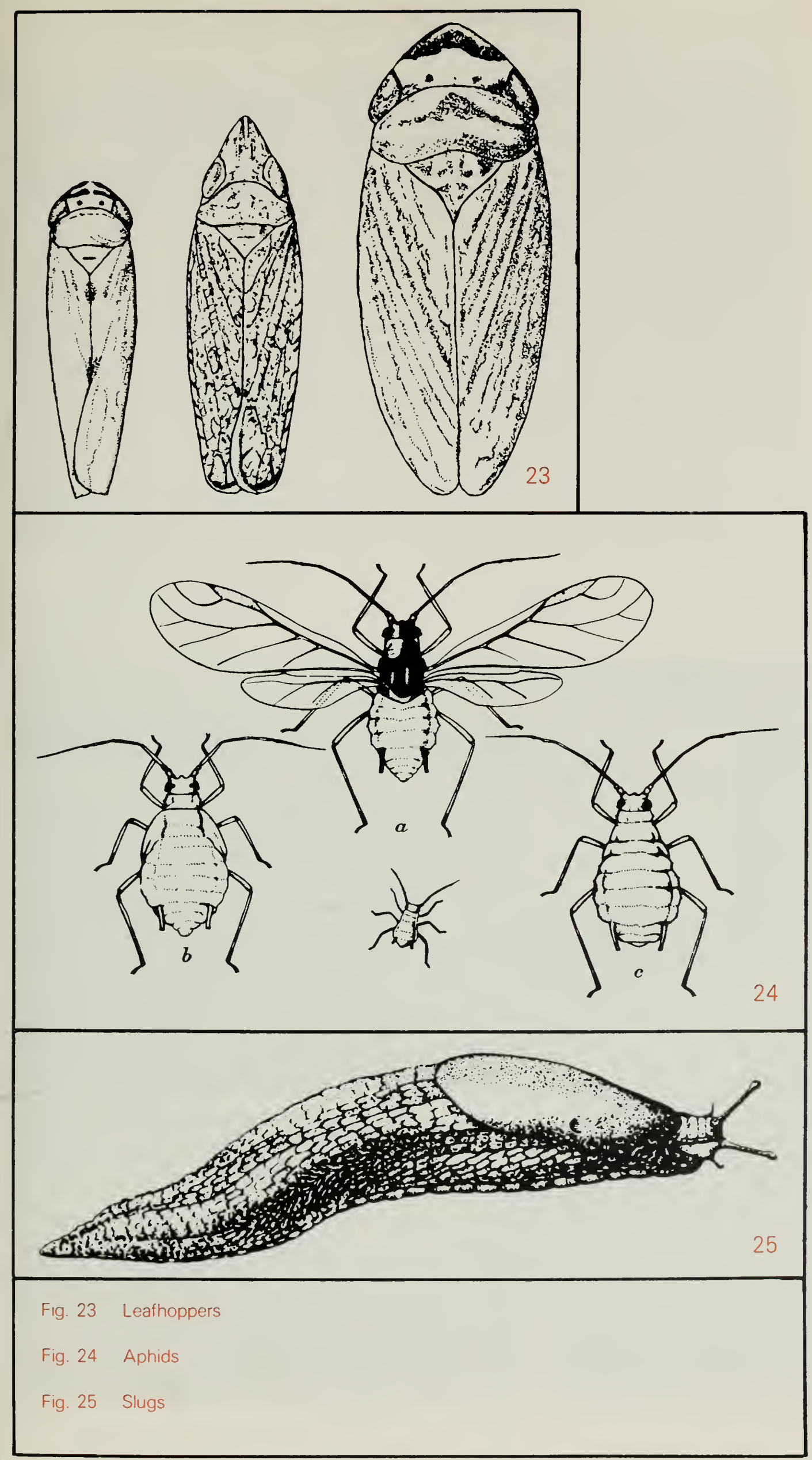


Strawberry diseases are present wherever the crop is grown. Often, they cause a reduction in yield, and if severe, may cause a complete crop failure. Diseases may affect any part of the strawberry plant and some of them require special control measures (Fig. 26). The following descriptions of the most serious strawberry diseases have been prepared to assist in their identification and control.

\section{FRUIT ROTS}

The most important diseases of strawberries are the fruit rots caused by several fungi. They are capable of ruining most of the crop. Losses from fruit rot are easy to see because it is the fruit that is destroyed. Picking and packing are more expensive when rots are present in the field. Losses from fruit rots vary each year and from locality to locality according to the weather conditions prevailing from first bloom through harvest.

GRAY MOLD (BOTRYTIS FRUIT ROT) - The causal fungus, Botrytis cinerea Pers., is very common and often causes serious losses in strawberries. The fungus overwinters on plant debris and on the older leaves of plants in the bed. In the spring as the temperature rises and under moist conditions, the

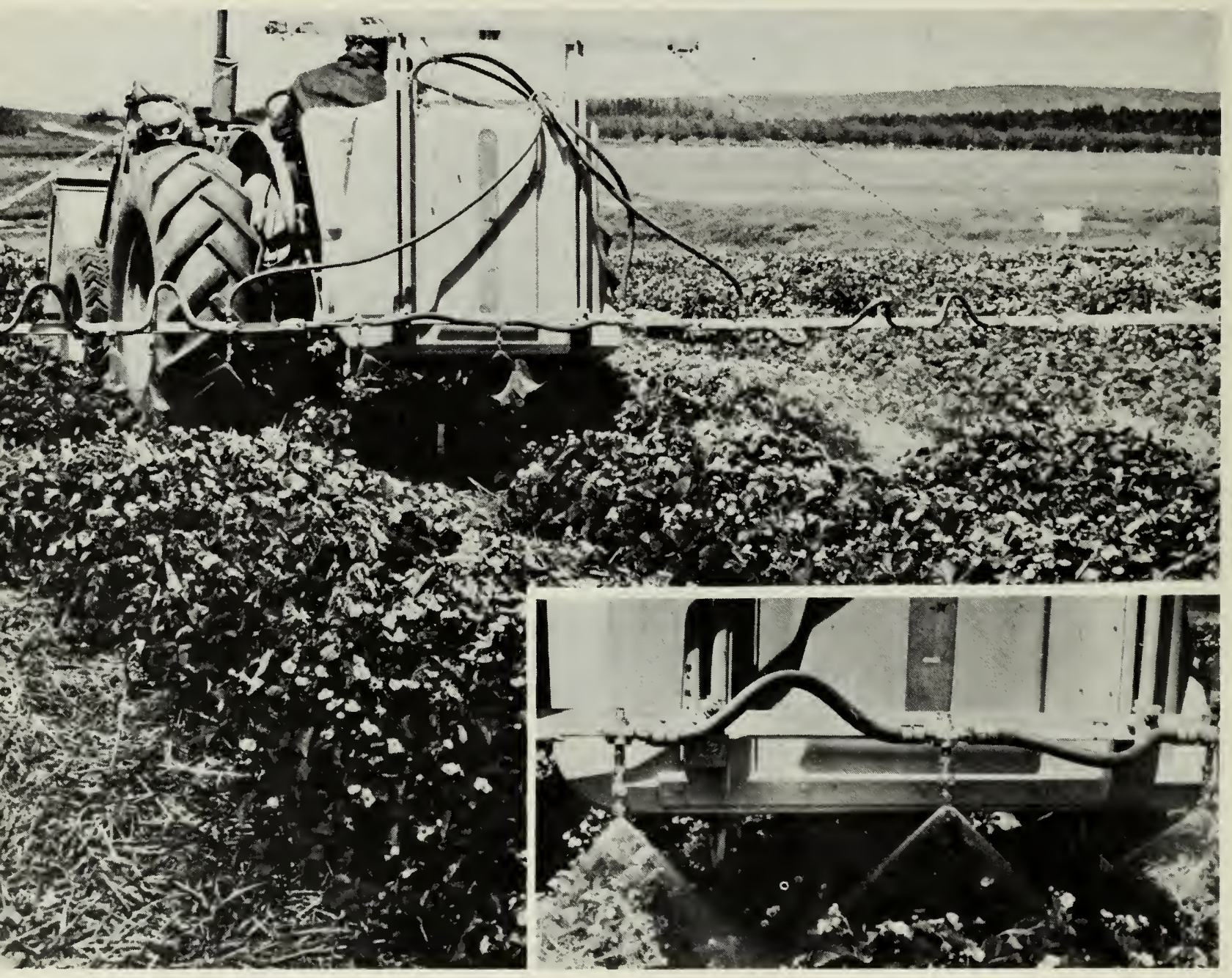


fungus produces numerous spores, which are scattered by rain, wind, and mechanical means to new infection sites. When conditions are suitable for the fungus, gray powdery masses of spores may be produced on infected tissue throughout the growing season. Gray mold affects blossoms, blossom stalks, and green and ripe fruit. Infections usually start in the blossoms and they may destroy the whole blossom stalk. Blossom infections may spread only as far as the calyx or hull, where the fungus can remain dormant until the fruit begins to ripen and then it reactivates, causing fruit rot. Often the botrytis fruit rot (Plate 1) or gray mold may not appear on ripe fruit until a day or two after the berries have been picked. On the fruit, the rot is rather soft and light brown. The fungus may spread directly to berries that are in contact with rotted berries or debris, or it may spread by spores that are blown or splashed to blossoms or berries. The disease is favored by shade or moisture. Any factor that produces soft fruit favors the development of fruit rot.

CONTROL - Control gray mold blossom blight and fruit rot by spraying with fungicides. Pay careful attention to proper timing of sprays and be sure to thoroughly cover all parts of the plant with the fungicide. Nitrogen fertilizer applied in the spring of the fruiting year promotes vigorous growth of the foliage that may encourage an outbreak of gray mold. Because rot may appear after harvest, pick and pack only sound fruit. Follow the recommendations outlined in your Provincial Strawberry Protection Guide.

RHIZOPUS ROT (LEAK) - Rhizopus fruit rot, caused by the fungus Rhizopus stolonifer (Ehrenb. ex Fr.) Lind., occurs mainly in berries that are shipped. The disease is commonly called "leak" because the juice runs from the collapsing berries and stains the boxes. It destroys fruit faster than any other rot. Most of the inoculum (spores of the fungus) gets on the berries in the packing shed and in the field.

The color of affected fruit soon changes to light brown and it may be covered by a whitish mold. The berries become soft and watery and collapse flat. Infection is found mainly on bruised or wounded berries, but the fungus can spread by direct contact. It develops above $10^{\circ} \mathrm{C}\left(50^{\circ} \mathrm{F}\right)$ and is most active at about $30^{\circ} \mathrm{C}\left(86^{\circ} \mathrm{F}\right)$.

\section{$\left(32^{\circ}\right.$ to $\left.40^{\circ} \mathrm{F}\right)$.}

CONTROL - Handle the fruit carefully and cool it quickly to $0^{\circ}$ to $4.5^{\circ} \mathrm{C}$

STEM-END ROT - Stem-end fruit rot, caused by the fungus Gnomonia fructicola (Arn.) Fall, is characterized by a brownish, firm rot usually at the calyx end of strawberry fruit. Infection occurs first on the calyx and from there the fungus may move into the fruit to cause a rot, which is more noticeable as the fruit begins to ripen. Infected calyxes may be present on mature fruit without any evidence of fruit rot. G. fructicola also causes leaf blotch.

BLACK SEED - Black seeds on the fruit are caused by the leaf spot fungus, Mycosphaerella fragariae (Tul.) Lindau. This disease is a problem only on the fruit of susceptible varieties.

POWDERY MILDEW - The fungus Sphaerotheca macularis (Wallr. ex Fr.) P. Magn. affects the fruit as well as the leaves. On susceptible varieties, the seeds or achenes of the fruit may be covered with a whitish growth of the mildew fungus, causing the berries to appear grayish.

Infection of the green fruit is the most damaging phase of the disease. Mildewed fruit does not develop or ripen normally and is a total loss.

CONTROL - Apply fungicides as outlined in your Provincial Strawberry

Protection Guide. 
Root diseases are the most lethal diseases of strawberries. Large areas of plantings may die suddenly or be so stunted that they produce few marketable berries. Root-rotting fungi live in the soil or are carried into clean fields on diseased plants, tools, or farm machinery.

BLACK ROOT ROT - This disease is caused by a number of different fungi that are common in most soils. Healthy young roots are white or clear. but when they are older, they become brownish or darker on the surface and have a yellowish living core or stele. Plants affected by root rot have reduced vigor and may die. Feeder roots die quickly. Darkened patches appear on the main roots and then the entire root, including the core blackens and decays.

Winter injury and poor drainage favor attack by root rot fungi. Failure of newly set plants to become established and the death of established plants before or during the picking season are caused by root rot.

The ultimate result of attack by root rot is death, although the length of time before the plants die depends on soil temperature, moisture, and growing practices.

CONTROL - To reduce damage from black root rot, obtain plants with clear white roots and plant them in well-drained soil. Use mulches and other good cultural practices to prevent injury to roots.

RED STELE - Red stele is caused by the fungus Phytophthora fragariae Hickman. It is very destructive, causing wilting or death of the plants. This disease is most active in cool weather, $0^{\circ}$ to $1.5^{\circ} \mathrm{C}\left(32^{\circ}\right.$ to $\left.35^{\circ} \mathrm{F}\right)$, and in cool, wet soil. It has been known to survive in infested soil for longer than 10 years. The most characteristic symptom of the disease is the red or reddish brown color of the stele or core of strawberry roots. No other disease or condition gives this red core symptom. It is most evident in roots from the start of growth in the spring until the harvest period, and in the fall. Affected plants may appear wilted, dwarfed, and dull in contrast with surrounding healthy plants. Often the first evidence of the disease is wilting of plants, especially in the lower parts of the planting, when the fruit begins to ripen. The red core or stele can be seen when the roots are split lengthwise or by stripping off the live outer portion with a knife or your thumbnail. Infected roots may appear healthy, except that they have a grayish cast, a rattail appearance (Fig. 27). and the small white feeder roots have rotted off. Some roots may have brown tips where the tissue has started to die. The red core may show only near the tip or may extend throughout the entire root. Severely affected plants die, others may appear to recover during warm summer weather, but they develop symptoms again during the fall and spring.

The causal fungus is introduced into new plantings mainly by infected plants. Spread within and to adjacent fields is mostly by soil carried by farming equipment and by washing rains that carry infested soil to new parts of the fields.

CONTROL - There is no known chemical control for red stele. Some varieties of strawberries can tolerate this disease in the field to such an extent that they may have some of their roots destroyed and still produce a profitable crop. The best practice is to use Certified plants and to avoid planting in soil that has been infested by red stele or in poorly drained or heavy soils.

VERTICILLIUM WILT - The causal fungi, Verticillium dahliae Kleb. and Verticillium albo-atrum Reinke \& Berth., are widespread and attack many fruit crops, vegetables, flowers, and trees, as well as strawberries. Some strawberry varieties may be more susceptible to $V$. dahliae than to $V$. albo-atrum, and vice 

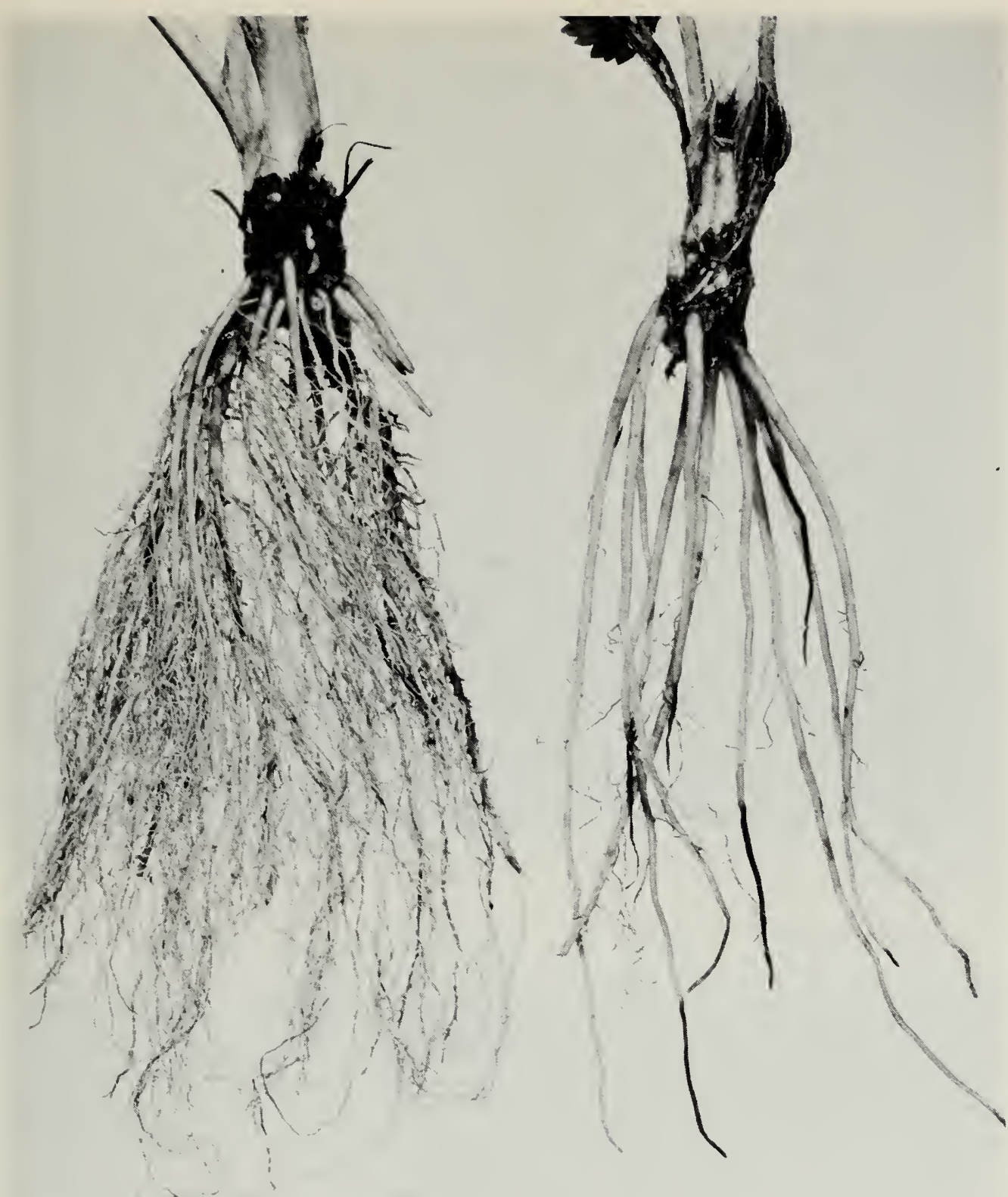

Fig. 27 The plant at left has a healthy root system. The plant at right is infected with red stele. Infected roots have a rattall appearance.

versa. In the Maritime Provinces, $V$. dahliae is found most often to cause wilt, whereas in Ontario, $V$. albo-atrum is the dominant species causing wilt. These fungi can survive in the soil for many years.

Symptoms of verticillium wilt are most evident in new strawberry plantings from about the time runners begin to form until late fall. Infected plants may die quickly, and others may die during the winter or be so weakened that they produce poor growth and little bloom the following season. Although this disease may appear in mother plants, the rooted daughter plants may not be affected. Verticillium wilt first appears as a wilting and drooping of the outer leaves. Black areas may appear on the petioles. The older leaves soon dry out, turn brown, and lie flat on the ground. New growth is retarded, resulting in a stunted, flattened plant. Symptoms of wilt can be confirmed only in the laboratory by culturing the fungus from infected plants.

CONTROL - Use as long a rotation system as possible and do not include crops such as egg plant, peppers, tomatoes, potatoes, or raspberries 
in your rotation. These fungi also cause wilt in other hosts, for example, verticillium wilt in maple trees, which may explain wilted strawberries occurring in land newly cleared of vegetation. Some strawberry varieties are more susceptible to fungi than others, but none are completely resistant. Do not plant susceptible varieties where the disease is likely to be troublesome.

\section{FOLIAGE DISEASES}

Foliage diseases are the most common and widespread diseases of strawberries. They overwinter in old leaves and other parts of plants. In the spring, leaf spot fungi become active when plant growth is well started. These fungi produce spores on the diseased parts of old leaves, and the spores are spread to new foliage by rain or your hands, tools, or clothing when plants are wet. New infections produce spores in 14 to 21 days. Damage from leaf spot varies with varieties, plant vigor, weather, and cultural practices. Losses are seldom severe where measures recommended for disease control have been applied.

LEAF SPOT - Symptoms of leaf spot (Plate 1) caused by Mycosphaerella fragariae (Tuhl.) Lindau first appear on leaves as purplish spots that are similar to the spots caused by leaf scorch. Later these spots enlarge from 3 to $6 \mathrm{~mm} / 1 / 8$ to $1 / 4 \mathrm{in}$.) in diameter and the centers become gray or white with reddish to purplish borders. Leaf petioles, fruit stalks, stolons (runners), and sometimes calyxes (caps or hulls) may be attacked. Plants and leaves are more susceptible to leaf spot early in the growing season and in late summer, especially where growth is very succulent. This fungus also causes black seed on the fruit.

LEAF SCORCH - The fungus Diplocarpon earliana (Ell. \& Ev.) Wolf causes many purple blotches up to $6 \mathrm{~mm} / 1 / 4 \mathrm{in}$.) in diameter. The centers of the blotches become brownish but not gray or white as in the case of leaf spot. Badly affected leaves dry up and their margins curl upward, so that they appear burned or scorched. The calyxes, petioles, stolons, and fruit stalks may be severely attacked. Unlike leaf spot, leaf scorch (Plate 2) attacks leaves and plants in all stages of growth, and serious infections may occur during the wet spring months.

LEAF BLIGHT - This disease caused by the fungus Phomopsis obscurans (Ell. \& Ev.) Sutton is easily recognized by large, red to brown spots surrounded by a purplish margin on the leaves. Spots range from 6 to $25 \mathrm{~mm}$ $(1 / 4$ to 1 in.) in diameter and may be circular, elongated, or $\mathrm{V}$-shaped. Black specks, the spore-producing bodies of the fungus, may dot the center of the spots. Leaf blight is most harmful on slow-growing or weak plants. Usually it affects the older leaves in late summer, after the fruit has been harvested.

LEAF BLOTCH - The leaf-spotting phase of leaf blotch (Plate 2), caused by Gnomonia fructicola (Arn.) Fall, is characterized by purplish to brownish blotches and sometimes by large brown spots that are somewhat similar to those of leaf blight. Calyxes, petioles, and fruit stems are also affected. This disease is common on older leaves in late summer. This fungus also causes stem-end fruit rot.

POWDERY MILDEW - The fungus Sphaerotheca macularis (Wallr. ex Fr.) P. Magn. affects all the aboveground plant parts. Leaves, calyxes of flowers, and fruit support growth of mildew. Infected leaves curl upward, become reddish on the underside, and in severe instances, develop badly burned areas at the edges of the leaves. The white, powdery growth of the fungus may be seen on the underside of severely infected leaves. Powdery 


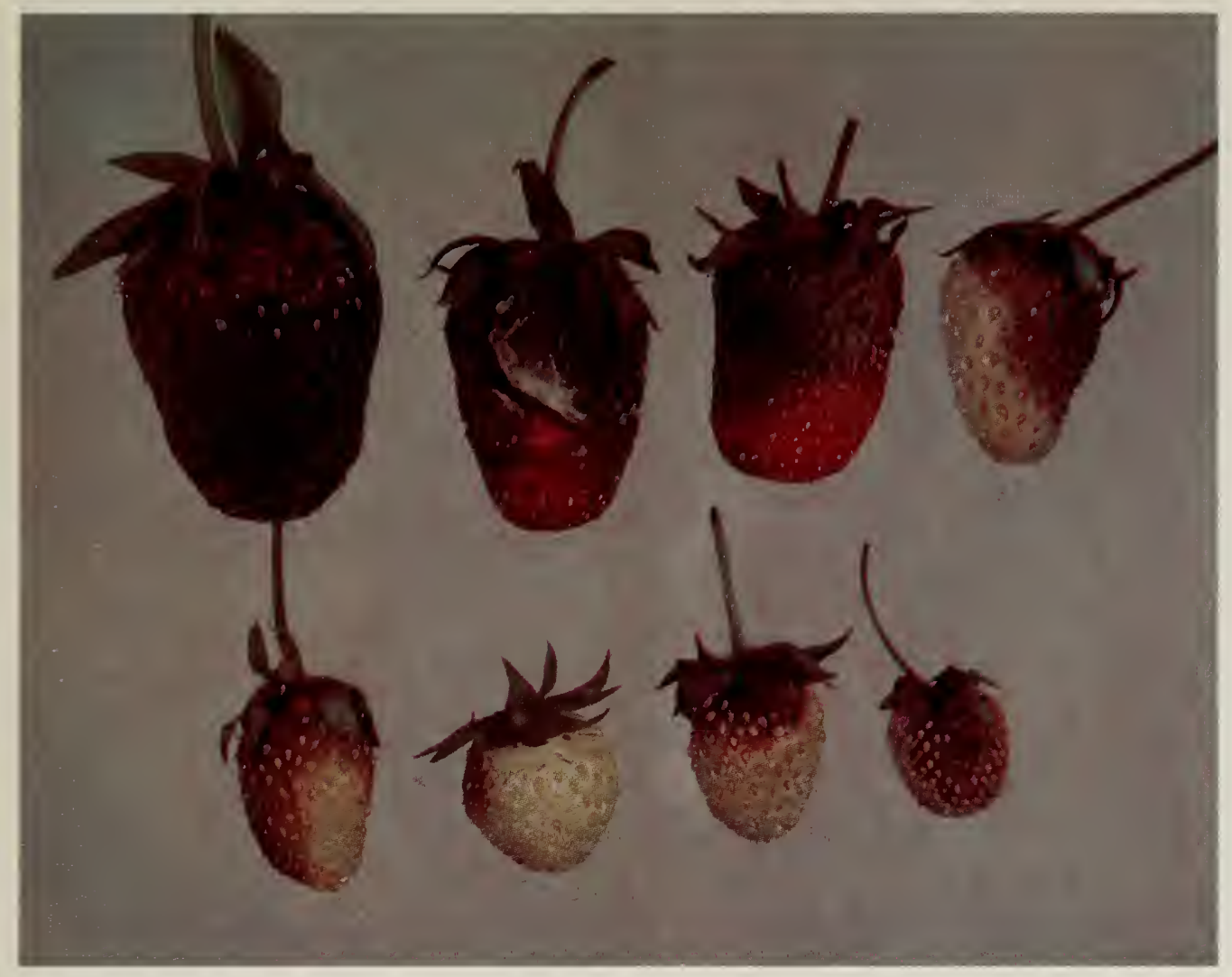

Plate 1 Strawberry fruit at different stages of maturity infected with botrytis fruit rot.

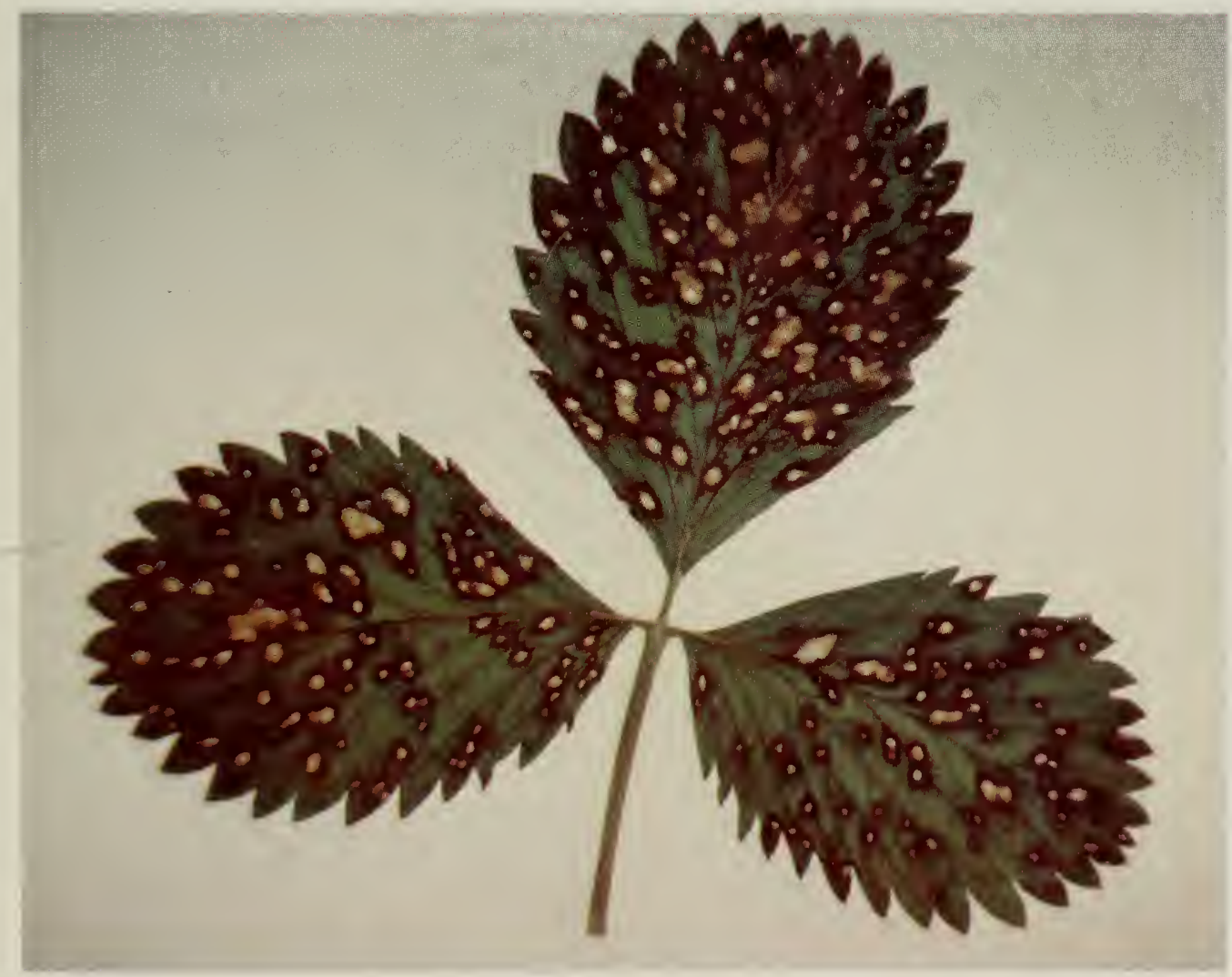




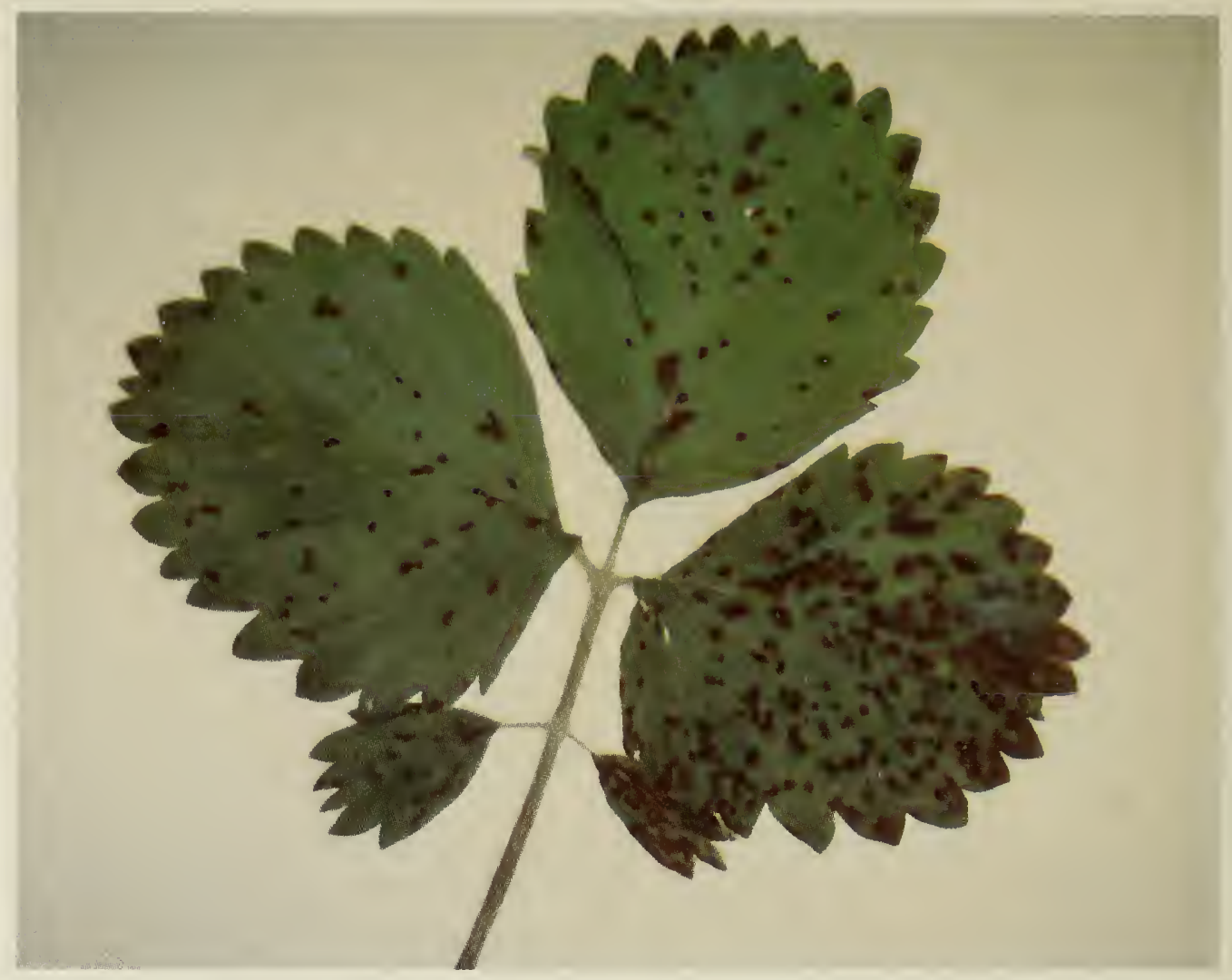

Plate 2 Leaf scorch

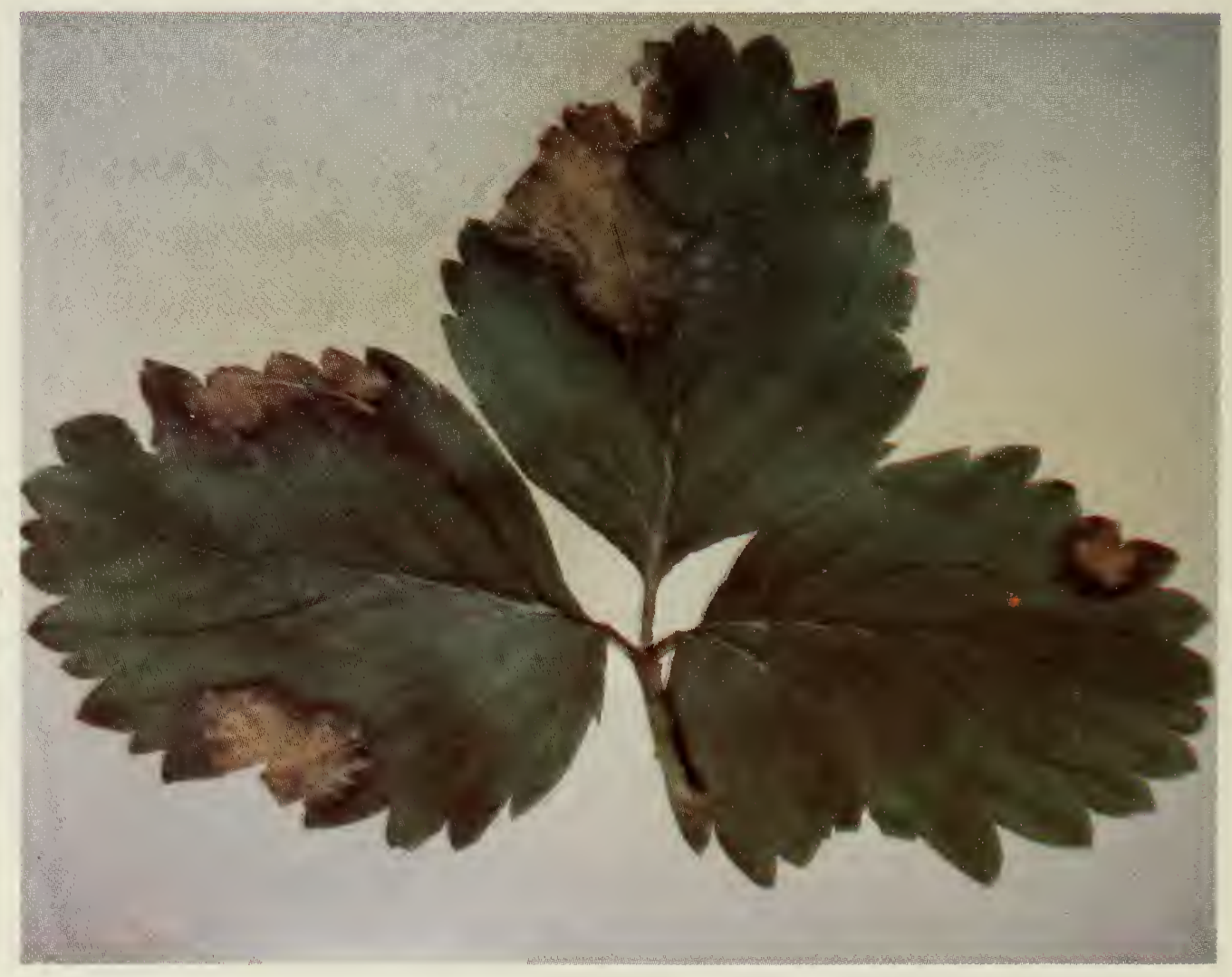

Leaf blotch 


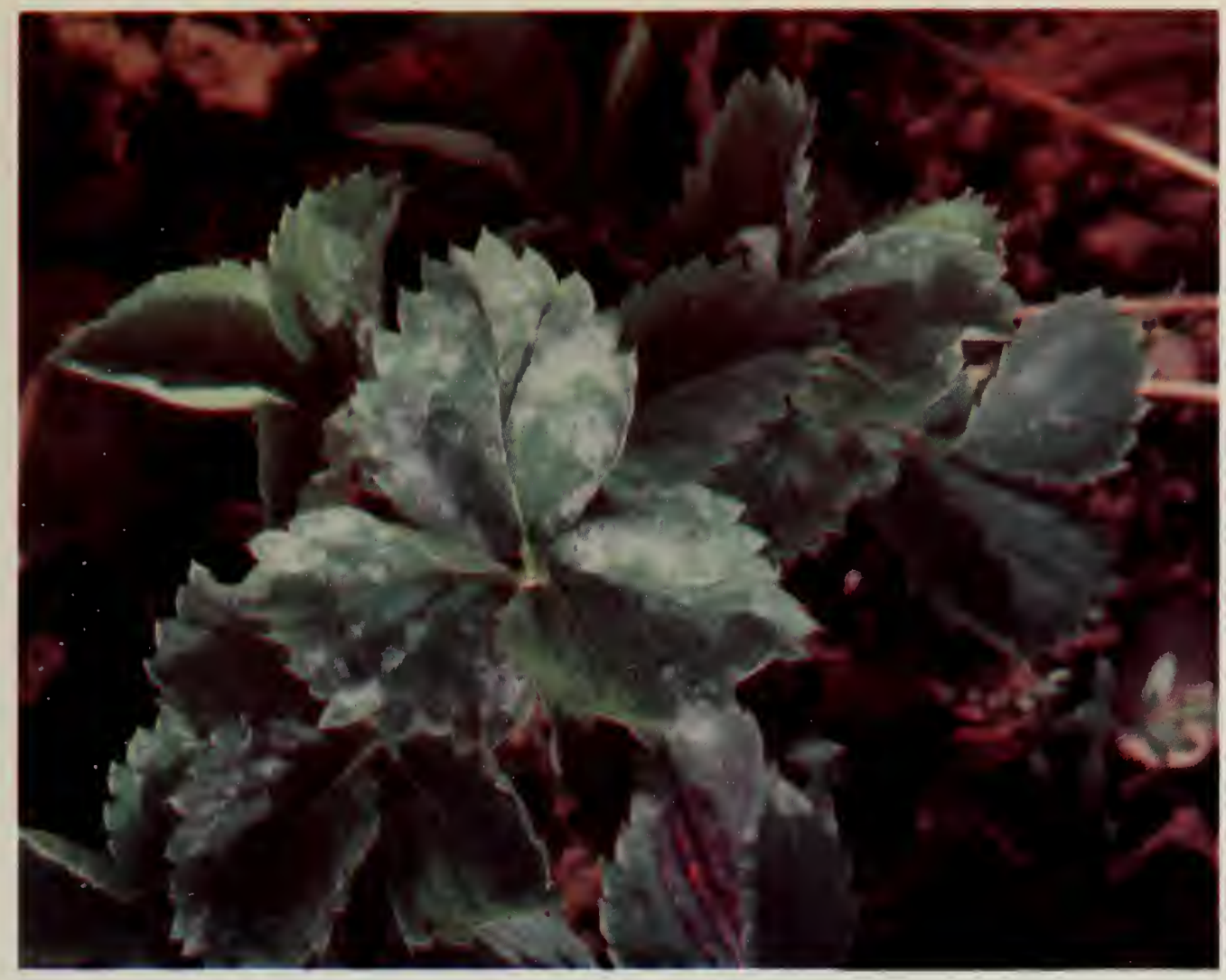

Plate 3 Powdery mildew

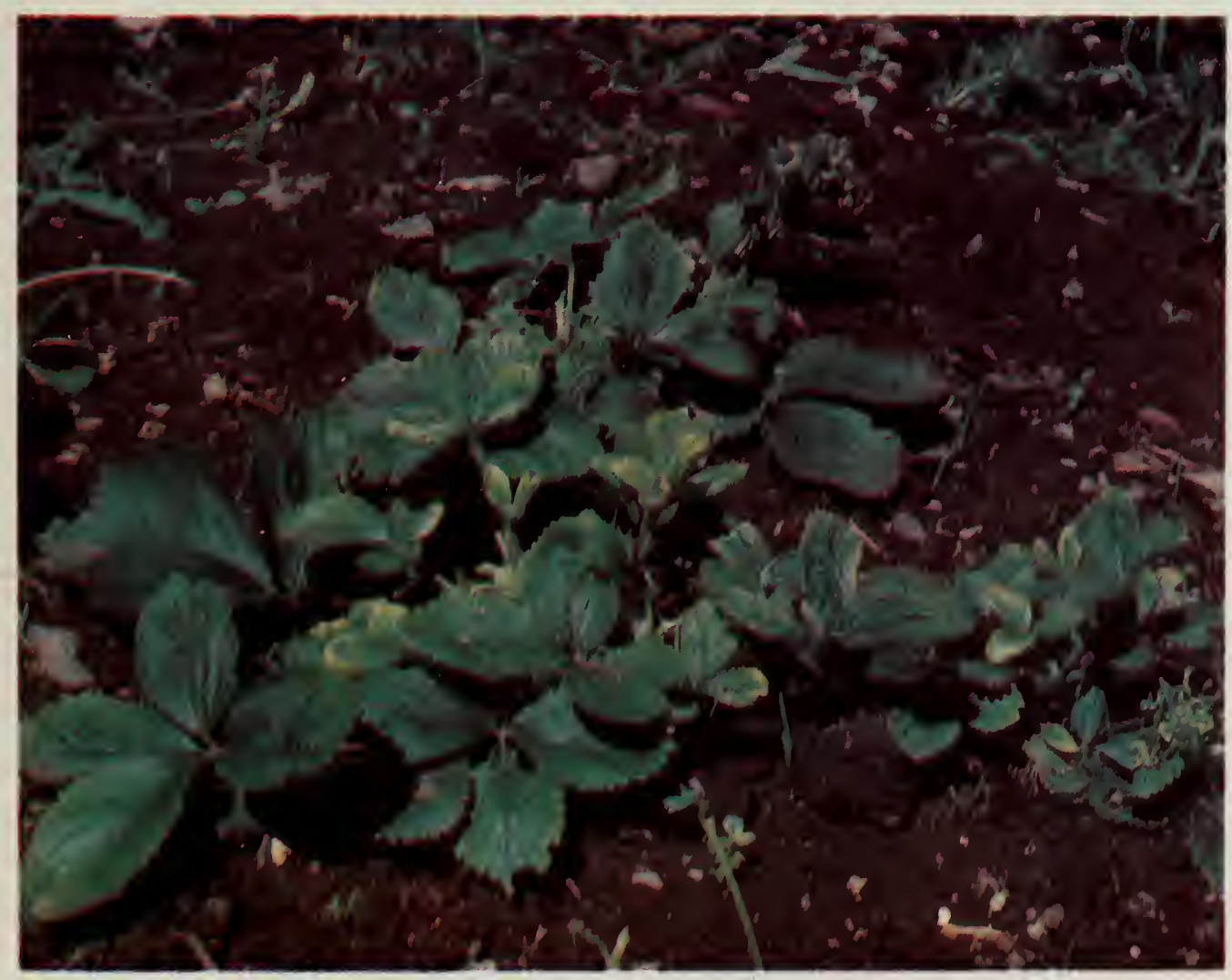

Green petal virus 
mildew (Plate 3 ) develops in the spring and fall, when conditions are usually most favorable for the disease.

In the spring, it begins to develop soon after plant growth starts, and its gradual spread may not be noticed until most of the plants in a field are affected. If a severe outbreak occurs before picking, the crop may be greatly reduced. On the leaves, the symptoms are most noticeable on hot, dry days.

CONTROL - For control of foliage diseases, consult the current Provincial Strawberry Protection Guide available from your Provincial Department of Agriculture.

TIP BURN - The cause of tip burn is not known, but evidence suggests it may be the result of a localized shortage of calcium occurring just before and during leaf emergence. It is not a lethal disease. High temperature in the spring or early summer, particularly as a sudden interruption in a rather steady cool period, induces tip burn. Terminal growing tissues of young unfolding leaves and flowers are killed. Affected leaves are irregularly shaped and puckered, appearing to be burned back from their tips. Vigorously growing succulent plants usually suffer greater injury than plants that grow more slowly.

\section{VIRUS DISEASES}

Virus diseases are identified by the symptoms shown on plants in the field or by indexing, which is done by grafting leaves onto virus-sensitive plants that readily express the symptoms of viruses that may be latent in the leaves of the donor plants. Generally the common name given to a virus disease is descriptive of the symptoms produced on the plant. These diseases are spread from plant to plant by insects (vectors), chiefly aphids and leafhoppers. When a plant becomes infected, it does not recover, and all plants attached to it by runners also become infected because the infectious agent is carried in the plant sap.

GREEN PETAL - The petals of flowers infected with this disease are dwarfed and pale green instead of white. If berries form, they are dark green, have prominent seeds, and do not ripen. On infected plants, new leaves are dwarfed and pale green or yellowish in color.

This green petal virus (Plate 3) disease of strawberry also causes phyllody (flower parts become leaf-like) on clover. It can be transmitted from clover to strawberry by leafhoppers. Green petal occurs in Quebec and in all the Maritime Provinces, except Newfoundland.

CONTROL - Remove suspected diseased plants from new set fields. Do not grow strawberries close to clover. Because this virus, which is spread by leafhoppers, is so infectious, new set plants may show symptoms of green petal disease any time after 1 or 2 months in the field.

ASTER YELLOWS - New leaves on infected plants are dwarfed, pale green or yellowish, and difficult to distinguish from plants infected with green petal.

CONTROL — Remove diseased plants.

MOTTLE, LATENT-C, VEINBANDING, CRINKLE, LEAF CURL, WITCHES'$B R O O M$ - These are infectious strawberry viruses. The so-called "running out" of plants and low yields often may be caused by one or more of these viruses. They are much less important now than in the past because of the virus-indexed plant-growing program in use.

A screenhouse (Fig. 28), which is an area of soil completely screened from virus vectors, is used by nurserymen to maintain a source of virus- 


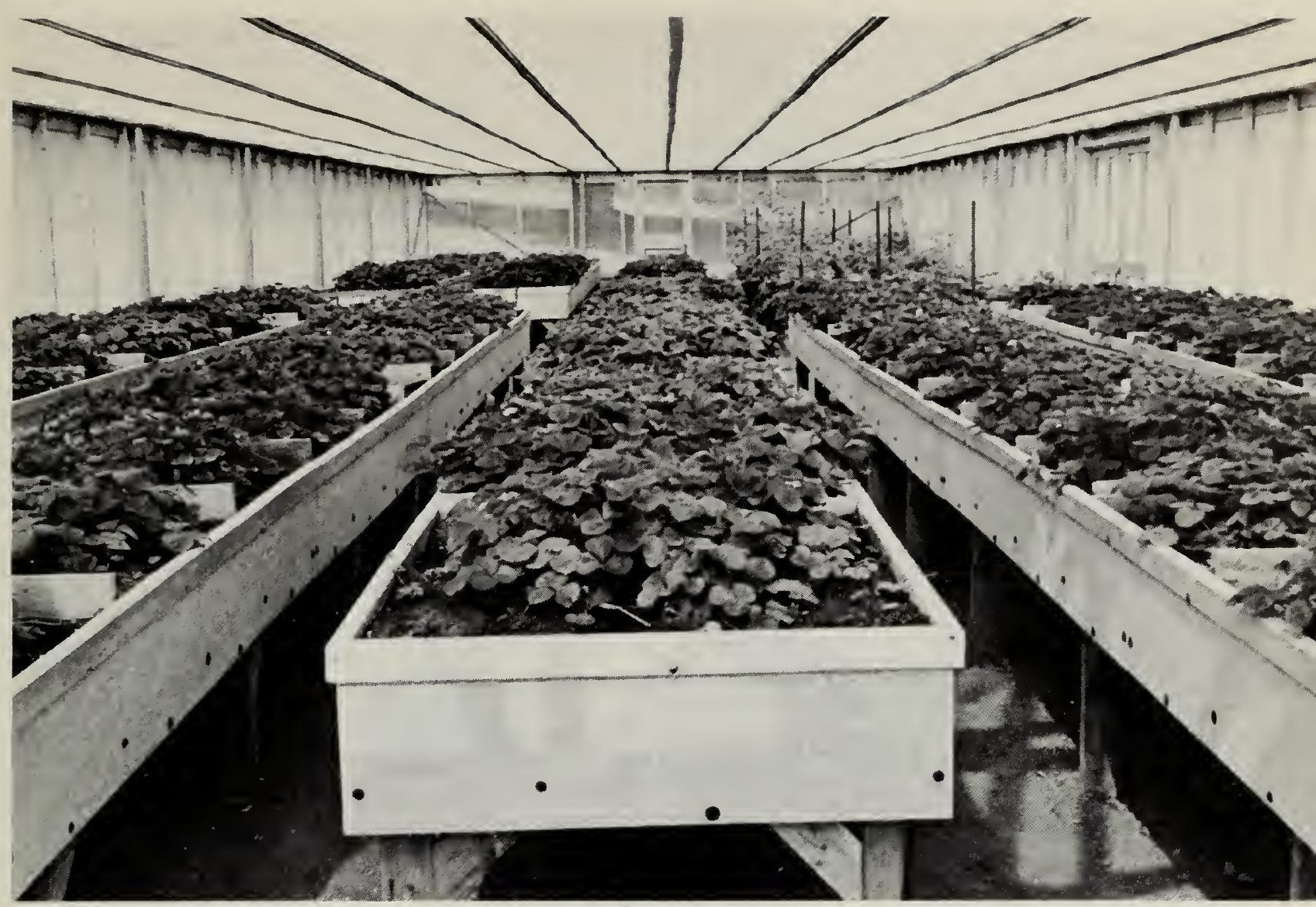

Fig. 28 Screenhouse to exclude virus transmitting insects.

indexed plants. The following year, these plants are multiplied in the field where insecticides are applied to control insects and to prevent the introduction and spread of virus diseases. The method of insect control must conform with Provincial Department of Agriculture regulations. Plants produced under this system that on inspection are found to be free of diseases can be sold as Certified plants.

CONTROL - Use Certified plants.

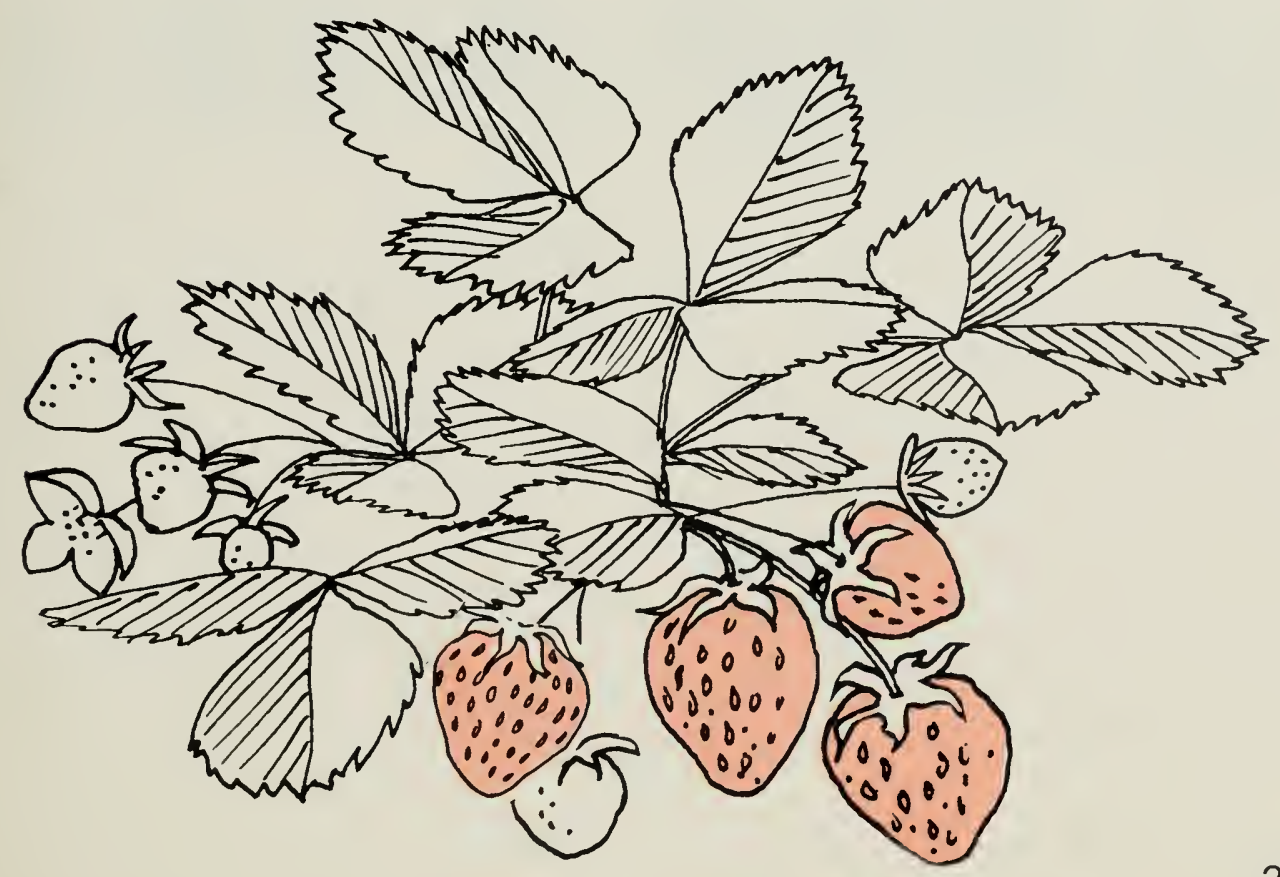




\section{LIST OF CREDITS FOR ILLUSTRATIONS}

Plates 1, 2, 3 (leaf spot), 4, 5

Figs. 1, 2, 3, 4, 5, 6, 7, 10, 11, 12 . $13,26,27$

Plate 3 (botrytis fruit rot)

Figs. 8 and 9

Fig. 14

Figs. 16, 17, 23, 25

Figs. 19 and 22

Figs. 20, 21, 24

Figs. 15 and 18
- Courtesy of Research Branch. Agriculture Canada, Kentville, Nova Scotia

- Courtesy of Ottawa Research Station. Agriculture Canada, Ottawa, Ontario

- Courtesy of New Brunswick Department of Agriculture and Rural Development

- Courtesy of D.B. Field, Weymouth, Nova Scotia

- Courtesy of Research Branch. Agriculture Canada,

Ottawa, Ontario

- Courtesy of Ohio Agricultural Research and Development Centre, U.S.A.

- Courtesy of United States Department of Agriculture

- Courtesy of Nova Scotia Department of Agriculture and Marketing

\section{ACKNOWLEDGMENTS}

The section on insects was prepared by Dr. A.W. MacPhee, Head, Entomology Section, Research Station, Kentville, N.S. Mr. C.O. Gourley, Plant

Pathology and Pesticide Residue Section, Research Station, Kentville, prepared the section on diseases. 


\section{CONVERSION FACTORS FOR METRIC SYSTEM}

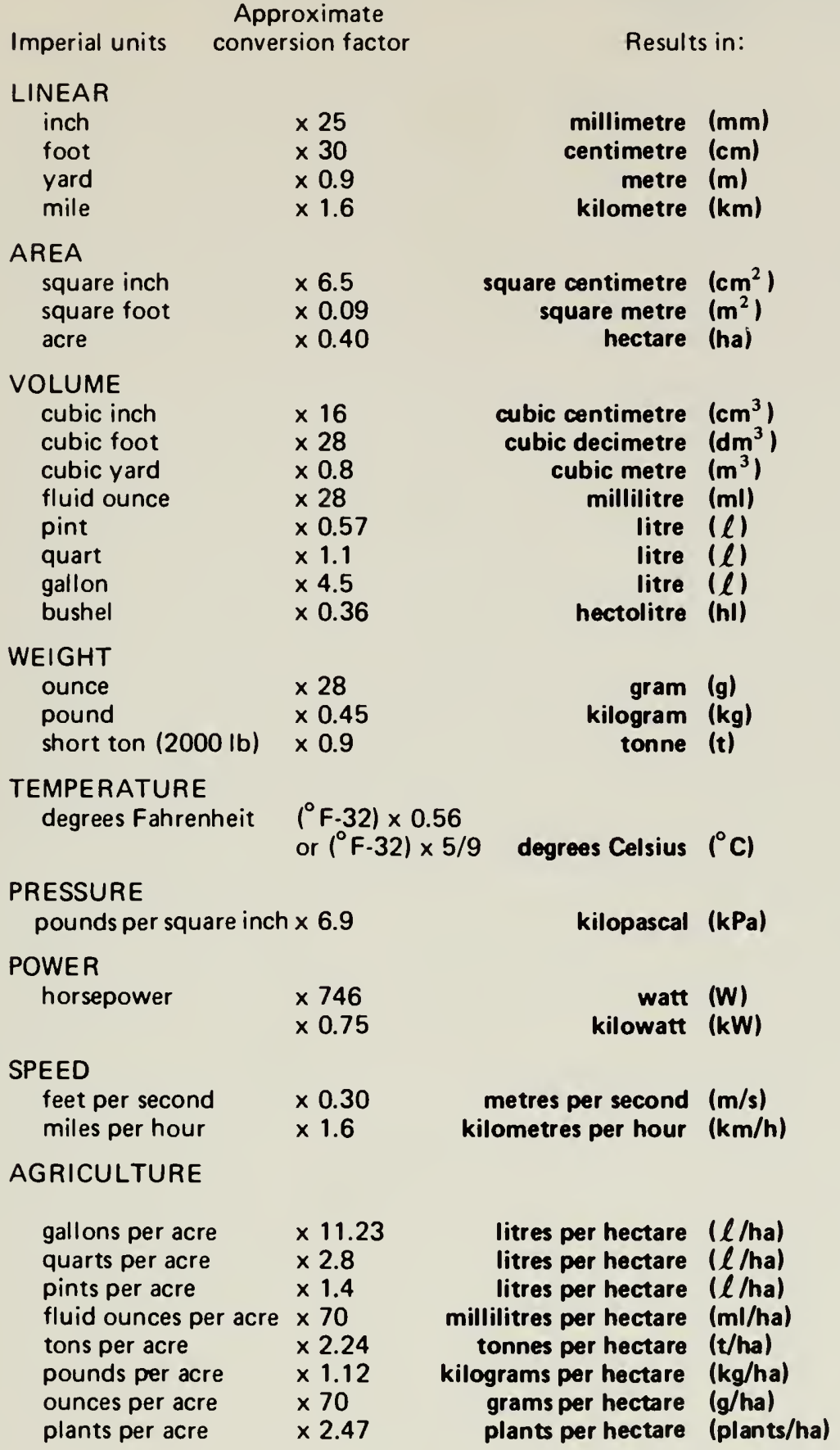



